\title{
KURUMSAL YÖNETIM ARACI OLARAK BAĞIMSIZ YÖNETIM KURULU ÜYELİĞİ: TAM BAĞIMSIZLIK MÜMKÜN MÜ?
}

\author{
Dr. Öğr. Üyesi Hatice Kübra KANDEMİR*
}

\begin{abstract}
ÖZET
Dünya genelinde kurumsal yönetim alanında benimsenmiş bir yönetim aracı olan bağımsız yönetim kurulu üyeliği uygulamasına, ülkemizde de 6362 sayılı Sermaye Piyasası Kanunu'nda ve Kurumsal Yönetim Tebliği No. II17.'nin ekinde yer alan Kurumsal Yönetim İlkelerinde yer verilmiştir. 6102 sayılı Türk Ticaret Kanunu'nda ise bağımsız yönetim kurulu üyelerine ilişkin Sermaye Piyasası Kanunu mevzuatında yer alan hükümlerin uygulanacağı belirtilmiştir. Buna göre, halka açık şirketlerinin yönetim kurullarında en az iki üyenin icrada görev almayan bağımsız üyeden oluşması öngörülmüştür. Bağımsız yöneticilerin yönetim kurullarındaki temel rolü, icradan sorumlu olan üyelerin faaliyetlerini izlemek ve şirket stratejisinin geliştirilmesine katkıda bulunmaktır. Bu çalışmada, bağımsız yönetim kurulu üyeliği için tasarlanan temel işlevleri özellikle yönetim kontrolünü elinde bulunduran pay sahiplerinin olduğu şirketler açısından sorgulanmıştır. Bu kapsamda, bağımsız yönetim kurulu üyeliğinin etkinliğinin önündeki başlıca engeller tespit edilmiştir. Ayrıca, bu çalışmada tam bağımsızlık için öne sürülen azlığın yönetim kurulunda temsil edilmesi önerileri irdelenmiş ve bu önerilerin eksik yanları değerlendirilmiştir.
\end{abstract}

Anahtar Kelimeler: Kurumsal Yönetim, Yönetim Kurulu, Bağımsız Üyeler, Kurumsal Yönetim İlkeleri, Yönetimde Temsil.

İzmir Katip Çelebi Üniversitesi İktisadi ve İdari Bilimler Fakültesi, Ticaret Hukuku Anabilim Dalı, haticekubra.kandemir@ikc.edu.tr, ORCID ID: 0000-0001-9722-1798, (Geliş Tarihi: 27.02.2020 - Kabul Tarihi: 01.05.2020). 


\title{
INDEPENDENT BOARD MEMBERSHIP AS A CORPORATE GOVERNANCE TOOL: IS FULL INDEPENDENCE POSSIBLE?
}

\begin{abstract}
In the field of corporate governance, independent board membership as a management tool adopted around the world; in our country, it is included in the Capital Markets Law and the Corporate Governance Principles in the annex of the Communiqué No. II-17.1. The Turkish Commercial Code numbered 6102 states that the Capital Markets Law provisions regarding the independent board members will be applied. Accordingly, it is required that at least two members of the board of directors of the public companies will be independent who do not have any executive duties. The main role of independent directors in the board is to monitor the activities of the executive members and to contribute to the development of the company strategy. In this study, the basic functions designed for the independent board membership are questioned especially in terms of the companies with controlling shareholders. In this context, major obstacles to the effectiveness of independent board membership have been identified. In addition, in this study, representation of the minority shareholders proposals for full independence in the board were examined and the shortcomings of these proposals were evaluated.
\end{abstract}

Keywords: Corporate Governance, Board of Directors, Independent Members, Corporate Governance Principles, Representation on the Board. 


\section{Gíriş}

Türk Ticaret Kanunu'na göre, anonim şirketlerin temsil ve idaresi yönetim kurulları eliyle yürütülür. Yönetim kurulu, şirketin işletilmesiyle ilgili ve genel kurulun yetkisinde bırakılmış bulunanlar dışında her konuda karar almaya yetkilidir (TTK, m. 374). Kanun, hem genel kurulun hem de yönetim kurulunun devredilemez görev ve yetkilerini belirlemiştir (TTK, m. 408, 375). Böylece, bir anonim şirket bünyesinde oluşturulan bu iki zorunlu organ arasındaki görev ve yetki dağılımının sınırları kanunla belirlenmiştir.

Yönetim kurulunun temel işlevi, şirketin üst düzeyde yönetimi ve gözetimi ile şirketin yönetim teşkilatının oluşturulmasıdır (TTK, m. 375). Bu kapsamda, yönetim kurulu, genel müdür ve yardımcılarını atayabilir, görevden alabilir (TTK, m. 375/1/d). Yönetim kurulu üyeleri ve yönetimle görevli üçüncü kişiler, bu görevlerini yerine getirirken, tedbirli bir yöneticinin özeniyle hareket ederek şirketin menfaatlerini korumakla yükümlüdür (TTK, m. 369). Bu özen yükümlülüğüne uyma şartıyla, yönetim kurulu şirketin işleri ile ilgili tarafsız ve bağımsız karar verebilme özgürlüğüne de sahip olmalıdır. ${ }^{1}$ Şirketin yönetsel performansının idaresini etkili bir şekilde yapabilmesi için, yönetim kurulunun objektif karar alma kabiliyetinin bulunması gerekir. Bir diğer ifade ile yönetim kurulu kendi görev ve yetki sınırları içerisinde kalan konularda, belirli bir kişi, grup veya bir organın tesiri olmadan, bağımsız karar alabilmelidir. Yönetim kurulunun tarafsızlığı ve bağımsızlığı, icradan sorumlu yönetici ve yönetim kurulu başkanlı̆̆ görevlerinin birbirinden ayrılması ile mümkün kılınabilir. İki görevin birbirinden ayrılması, uygun bir güç dengesi sağlanmasına, hesap verebilirliğin artırılmasına ve yönetim kurulundan bağımsız karar alma kabiliyetinin artırılmasına hizmet edecektir. ${ }^{2}$ Yönetim kurulunda kararların alınmasında farklı görüşlerin değerlendirilip değerlendirilmediği ya da yönetim kurulu kararlarının sorgulamaya açı olup olmadığı yönetimin etkinliğinin ölçülmesinde dikkate alınan kriterlerdir. Dolayısıyla, yönetim kurulu başkanı ve genel müdür görevlerinin birbirinden ayrılması yönetim kurulu kararlarının sorgulanma kalitesinin artırılmasına

OECD (2016), G20/OECD Principles of Corporate Governance (Turkish version), OECD Publishing, Paris. <http://dx.doi.org/10.1787/9789264236882-en> s.e.t. 21.02.2020

2

OECD, s. 57. 
hizmet edebilir. ${ }^{3} \mathrm{KY}$ İlkeleri'nde yönetim kurulu başkanı ile icra başkanı/genel müdürün aynı kişi olmaması gerektiği hususu, "şirkette hiç kimse tek başına sınırsız karar verme yetkisi ile donatılmamalıdır" görüşüyle ifade edilmiştir (m. 4.2.5). ${ }^{4}$

Yönetim kurulunun tarafsız olması, hakim bir hissedarın yönetim kurulu ve yönetimi atama konusunda önemli etkileri olduğu şirketlerde daha da önem kazanır. Bu tür yönetim kontrolünü ${ }^{5}$ elinde bulunduran pay sahiplerinin olduğu şirketlerde, yönetim kurulunun tarafsızlığı, yeterli sayıda kurul üyesinin yönetimden bağımsız olmasını gerektirmektedir. Bağımsızlık, yeterli sayıda üyenin şirket veya iştirakleri tarafından istihdam edilmemesini ve önemli ekonomik, aile veya diğer bağlarla şirket veya yönetimiyle yakından ilişkili olmamasını ifade eder. Bağımsız üyeler, icrada yetkisi ve görevi olmayan yönetim kurulu üyeleri arasından seçilir (KY İlkeleri, m. 4.3.3). KY İlkeleri, halka açık anonim ortaklıklarda icrada görevli olan - olmayan üye yapılanmasını zorunlu hale getirmiştir. Buna göre, yönetim kurulunun çoğunluğunu icrada görevli olmayan üyeler oluşturur (m. 4.3.2). İcra yetkisi olan üyeler, şirketin günlük işlerinde aktif rol oynarken yönetim işlerine daha fazla mesai harcarlar; ${ }^{6}$ icra yetkisi olmayan üyeler ise, yönetim kurulu bünyesinde yönetimi gözetleme ve denetim görevlerini yerine getirirler, ancak şirketin günlük işleri ile ilgili görev almazlar ve aktif yönetime katılmazlar. ${ }^{7}$

3 Argüden, Yllmaz (2009) Boardroom Secrets: Corporate Governance for Quality of Life, Palgrave Macmillan.

4 Ancak, KY İlkeleri bu yetkilerin ayrıştırılması gereğini ifade etmiş olsa da, bu yetkilerin birleşmesini yasaklamamıştır. Sadece, yönetim kurulu başkanı ve icra başkanının aynı kişi olmasına karar verilmesi durumunda bu hususun gerekçesiyle birlikte KAP 'ta açıklanması zorunlu tutulmuştur (m. 4.2.6).

5 SerPKn m. 26(2) hükmü uyarınca, “ortaklı̆̆ın oy haklarının yüzde ellisinden fazlasına tek başına veya birlikte hareket ettikleri kişilerle beraber, doğrudan veya dolaylı olarak sahip olunması ve yönetim kurulu üye sayısının salt çoğunluğunu seçme veya genel kurula söz konusu sayıdaki üyelikler için aday gösterme hakkını veren imtiyazlı paylara sahip olunması" yönetim kontrolünün varlığı olarak kabul edilir.

6 Gürbüz Usluel, Aslı E. (2019) “İcra Kurulu”, Türkiye Barolar Birliği Dergisi, 142, s. 373.

7 Aksoy, Mehmet Ali (2013) "Türk Kurumsal Yönetim Düzenlemeleri Kapsamında Anonim Şirket Yönetim Kurulu”, Gazi Üniversitesi Hukuk Fakültesi Dergisi, C:17, S:1-2, s. 54. 
Yönetim kontrolünü elinde bulunduran hakim hissedarların bulunduğu şirketlerde, yönetim kurulu, sermayenin çoğunluğunu elinde bulunduran hakim grubun talimatlarına göre hareket etmek durumunda kalabilir. Yönetsel karar sürecinin hakim hissedarların çıkarlarına öncelik verdiği şirketlerde küçük hissedarların haklarının istismarı riski vardır. ${ }^{8}$ Bu tip şirketlerde ayrıca şirket menfaatine aykırı kararların alınması da muhtemeldir. Hakim grubun şirket varlıklarını bireysel çıkarları uğruna kullandığı durumlar genel olarak şu yöntemler izlenerek ortaya çıkar: (i) ilişkili-taraf-işlemleri yoluyla; kontrol ettikleri şirketlere, kendileri için uygun şekilde mal veya hizmet satmak (veya almak), (ii) hisse senedi işlemleri yoluyla; pay sahiplerinden piyasa fiyatının altında hisse senedi satın alma, ve (iii) yüklü ödemeler yoluyla; hakim hissedarlara veya aile şirketlerine yüklü tazminat ve ikramiye ödemeleri yaparak.

Yöneticilerin ve hakim hissedarların bu tür fırsatçı davranışlarını engellemek üzere ortaya konmuş kurumsal yönetim stratejilerinden biri "güvenilir kişi (vekil) stratejisi"dir (trusteeship strategy). Bu strateji, ekonomik teşviklerin yokluğunda yöneticilerin etik/ahlaki ve itibari teşviklere cevap vereceğini ve bu nedenle şirketi pay sahiplerinin çıkarları doğrultusunda yönetme olasılıklarının daha yüksek olduğunu varsaymaktadır. ${ }^{9}$ Güvenilir kişi stratejisinin bilinen bir örneği yönetim kurullarında görevlendirilen bağımsız üyelerdir. Bağımsız yöneticilerin, kontrolörlere bireysel çıkar sağlayan eylemlerden kişisel olarak faydalanmayacaklarından dolayı karar alırken vicdani ve itibari teşvikler tarafından daha güçlü bir şekilde yönlendirilebilecekleri varsayılır. Bu doğrultuda, KY İlkeleri, yönetim kurullarında bağımsız yöneticilerin görevlendirilmesini öngörerek ve teşvik ederek, bireysel çıkarlara hizmet eden kararların alınmasında bağımsız üyelere başvurulmasını ve çıkar çatışmasının oluşmasını önlemeyi amaçlar.

$\mathrm{Bu}$ makalede bağımsız yöneticilerin kurumsal yönetimdeki rolü ve işlevi özellikle hakim hissedarların bulunduğu şirketler açısından

8 Armour, John/Hansmann, Henry/Kraakman, Reiner (2009) European Corporate Governance Institute, Agency Problems, Legal Strategies and Enforcement, Law Working Paper No. 135/2009, November <https://sssrn.com/abstract=1436555> s.e.t. 21.02.2020

Armour/Hansmann/Kraakman, s. 10. 
değerlendirilecektir. Bağımsız yöneticilerin özellikle izleme ve denetim işlevlerini gerçekleştirmelerinin önündeki engeller tespit edilerek bağımsızlığının güçlendirilmesi yönünde alternatif öneriler değerlendirilecektir.

\section{DÜNYA'DA BAĞIMSIZ ÜYELER}

Bağımsız yöneticiler, dünya genelinde iyi kurumsal yönetim ile bağlantılı bir araç olarak kabul edilmektedir. Ancak, dünya genelinde kabul edilen ve uygulanan tek bir bağımsız yönetici tanımı ve buna göre oluşturan bir sistem yoktur. Bir kurumsal yönetim aracı olarak, yönetim kurullarında bağımsız yöneticilerin istihdam edilmesi uygulaması, ülkelerin kendilerine özgü hukuki ve kurumsal yapılarına bağlı olarak değişiklik gösterebilir. ${ }^{10}$

\section{A. AMERİKA BİRLEŞİK DEVLETLERİ (ABD)}

ABD'de bağımsız üyelik sisteminin, iki farklı probleme çözüm olarak geliştirildiği ifade edilebilir. Birincisi, yöneticilerin kendi menfaatlerine ya da hakim hissedarların çıkarlarına hizmet etmelerini engellemek, buna karşılık pay sahiplerine ve onların amaçlarına sadık kalmalarını sağlamaktır. ${ }^{11}$ İkincisi ise, şirketin kamuyu aydınlatma ve şeffaflık açıklamalarının güvenilirliğini artırmaktır. İlk amaca yönelik olarak, CEO’nun yönetim kurulu üzerindeki etkisini azaltmak amacıyla, bağımsız üyelerin yönetim kurullarında yer verilmesi gündeme gelmiştir. ABD'de yönetim kurulları, CEO’nun gücünü kontrol eden ve dengeleyen bir kuruldan ziyade genellikle CEO'nun güdümünde kalmıştır. ${ }^{12}$ Bunun nedeni, CEO’ların yönetici seçimi üzerinde önemli bir etkiye sahip olmasıdır. Bu durumu ortadan kaldırmak üzere,

10 Spiegel, Torsten (2018) Max Planck Institute for Comparative and International Private Law, Independent Directors in Japan: Changing Corporate Governance, Research Paper Series No. 18/23, s. 96. <https://ssrn.com/abstract=3299495> s.e.t. 21.02.2020.

11 Gordon, Jeffrey N. (2007) "The Rise of Independent Directors in the United States, 19502005: Of Shareholder Value and Stock Market Prices”, Stanford Law Review, 59, s. 1469.

12 Becht, Marco/Bolton, Patrick/Röell, Ailsa (2007) "Corporate Law and Governance": Polinsky, A. Mitchell \& Shavel, Steven (editörler), A Handbook of Law and Economics, Volume 2, Elsevier, s. 859. 
ABD'de Sarbanes - Oxley Yasası (2002) ve borsa listeleme standartları ile sermayesi dağınık olan şirket yönetim kurullarının çoğunluğunun bağımsız yöneticilerden oluşması öngörüldü.

Bağımsız yöneticiler, yönetici ücretleri ve tazminatı, denetçi atanması ve belirli aday gösterme kararları gibi pay sahipleri ile yönetim arasında çıar çatışması doğurabilecek meselelerle ilgili karar vermekle sorumludur. ABD'de bağımsız yönetici sayısı, yasal teşvikler ve federal düzenlemeler nedeniyle zaman içinde önemli ölçüde artmıştır. ${ }^{13}$ Örneğin, NYSE Listeleme Kuralları, yalnızca bağımsız üyelerden oluşan bir ücret komitesi kurulmasını öngörür (section 303A.01). Bunun yanı sıra, borsadaki her şirketin bir denetim komitesi oluşturması ve her üyenin bağımsızlık şartını yerine getirmesi gerekmektedir.

\section{B. DİĞER DEVLETLER}

$\mathrm{AB}$ düzeyinde bağımsız yöneticiliğin tanımı ve işlevi konusunda belirli bir seviyede mutabakata varıldığını söylemek yanlış olmaz. AB Komisyonu 2005 yılında yayınladığı bir tavsiye metninde, üye ülkelerin, yöneticilerin hakim pay sahiplerinden bağımsız olmalarını gerektiren kurumsal yönetim standardını benimsemeleri gereğine yer verdi. ${ }^{14}$ Buna göre, üye devletler, aşağıda sıralanan düzenlemelerden birini veya daha fazlasını kabul etmiştir. İlk olarak, üye ülkelerin halka açık şirket yönetim kurullarında bağımsız yöneticilere yer vermeleri gerekmektedir. İkincisi, bağımsız yöneticiler, yönetimin ve hakim pay sahiplerinin gözetiminde aktif rol oynayan komitelerde görev almalıdır. Üçüncüsü, bağımsız yöneticilerin özellikle ilişkili taraf işlemlerini incelemede etkin bir rol oynaması sağlanmalıdır. $\mathrm{Bu}$ düzenlemelere göre, Avrupa'da bağımsız yöneticilerin öncelikle şirketin denetim komitesinde görev alması beklenir. ${ }^{15}$ Buna göre, üye

3 Gordon, s. 1495.

14 European Commission Recommendation 2005/162/EC of 15 Feb. 2005, 2005 O.J. (L 52) $52,63$.

15 Spiegel, s. 96. 
devletlerarasında, denetim komitelerinin çoğunluğu (veya üçte ikisi) veya üyelerin tamamının bağımsız üyelerden oluşması öngörülmektedir. ${ }^{16}$

İngiltere Kurumsal Yönetim Kodu, bağımsı yöneticilerin görevlendirilmesi şartını sadece Ana Pazardaki (Main Market) en değerli borsa şirketleri için getirmiştir. Hakim bir yapının sermayenin bir bölümünü veya çoğunluğunu elinde tuttuğu şirketler, İngiltere Ana Pazarında nadir de olsa yer almaktadır. Bu tür şirketlerdeki azlık statüde yer alan pay sahiplerini korumak üzere yönetim kontrolünü elinde bulunduranların şirket üzerindeki etkisinin kısıtlanmasını sağlamak üzere bağımsı yöneticilerin görevlendirilmesi öngörülür. Böylece, hakim hissedarların etkisi, bağımsız yöneticiler vasıtası ile sınırlandırılmaya çalışılmıştır. Bağımsız üyelerin temel rolü, $\mathrm{AB}$ düzenlemeleri ile paralel doğrultuda, ilişkili-taraf-işlemlerinin onaylanmasıdır. İngiltere sermaye piyasasında sorumlu otorite olan FCA tarafından yayınlanan Listeleme Kuralları, ilişkili taraf işlemleri için genel kurul onayını şart koşar; ancak genel kurul onay şartı bir eşiğe tabidir. ${ }^{17}$ Bağımsız yönetici görevlendirmesi yapılmadığı takdirde, ilişkili taraf işlemleri ile ilgili hükümler, söz konusu eşikler kaldırılmış olarak uygulanır. Dolayısıyla, bağımsız yöneticilerin görevlendirilmediği hallerde, şirket ile kontrolör arasındaki işlemler, herhangi bir eşik değer aranmadan, genel kurul onayına sunulacaktır. Bu durum, yönetimi kontrolünü elinde bulunduran pay sahipleri için etkili bir yaptırım olarak görülür. ${ }^{18}$

16 Ferrarini, Guido/Filippelli, Marilena (2014) European Corporate Governance Institute, Independent Directors and Controlling Shareholders around the World, Law Working Paper No. 258/2014, ss. 23-27. <https://ssrn.com/abstract=2443786> s.e.t. 21.02.2020.

17 Genel kurul onayının aranması için, işlemin şirketin varlıklarının, cirosunun, karının veya piyasa değerinin \%5’ine eşit veya bu değeri aşıyor olması gerekir. Bu eşiğin altında ancak $\% 0.25$ 'lik bir eşiğin üzerindeki işlemler için genel kurul onayı aranmaz ancak bu durum kamuya açıklanmalıdır. Bkz. Financial Conduct Authority (FCA), Listing Rules (2014) Listing Regime Enhancements, Instrument. $<$ https://www.handbook.fca.org.uk/instrument/2014/FCA_2014_33.pdf> s.e.t. 21.02.2020.

18 Davies, Paul (2019) "Related Party Transactions: UK Model”: Enriques, L. \& Tröger, T. (editörler), The Law and Finance of Related Party Transactions International Corporate Law and Financial Market Regulation, Cambridge, Cambridge University Press, ss. 361399. 
Alman Kurumsal Yönetim Kodu (German Corporate Governance Code - GCGC) İngiltere örneği olan 'uygula ya da açıkla' prensibini benimsemiştir. Ancak GCGC, aynı zamanda Alman Anonim Şirketler Kanunu’na (German Stock Corporation Act) da dahil edilmiştir. Dolayısıyla, halka açık şirketler, Alman Kurumsal Yönetim Koduna uyum raporlarını açıklama veya Kodun tavsiyelerinden ne ölçüde ve niçin saptıklarını açıklama konusunda yasal yükümlülük altındadırlar. ${ }^{19}$ Alman kurumsal yönetim sistemi iki-kısımlı yönetim organı yapısına sahiptir; bunlar yönetim kurulu ve denetim kuruludur. Yönetim kurullarının bağımsızlıkları ile ilgili olarak ise, Kod herhangi bir oran telaffuz etmez ancak denetim kurullarında "yeterli sayıda" bağımsız üyenin bulunmasını şart koşar (GCGC, m. 5.4.2). Denetim kurulunun bağımsızlığının, yönetime karşı izleme ve gözetim fonksiyonunu güçlendirmesi beklenmektedir. ${ }^{20}$

\section{TÜRK KURUMSAL YÖNETIM SİSTEMINDE BAĞIMSIZ YÖNETIMM KURULU ÜYELİĞİ}

\section{A. HUKUKİ YERİ}

Bağımsız yönetim kurulu üyeliği 6762 sayılı TTK'da düzenlenmemiştir. Bağımsız yöneticiler ile ilgili ilk düzenleme SPK Kurumsal Yönetim İlkelerinde yer almıştır. 6102 sayılı TTK 'da ise bağımsız yönetim kurulu üyelerine ilişkin SPK mevzuatında yer alan hükümlerin uygulanacağ 1 belirtilmiştir (TTK, m. 360). SPK Kurumsal Yönetim İlkeleri’ne göre, yönetim kurulu üyelerinin çoğunluğu icrada görevli olmayan üyelerden oluşur ve bu üyeler arasında, görevlerini hiçbir etki altında kalmaksızın yapabilme niteliğine sahip bağımsız üyeler bulunur (KY İlkeleri, m. 4.3.2, 4.3.3). İcrada görevli olmayan ve bağımsız üyeler, şirketin herhangi bir hissesini elinde bulundurmadan yönetim kurulu üyesi olan gerçek bir kişidir. Bağımsız

19 Du Plessis, Jean J./Saenger, Ingo (2017) “An Overview of Corporate Governance Debate in Germany”: Du Plessis, Jean J./Lutterman, Claus/Sandrock,Otto/Großfeld, Bemhard/Sænger, Ingo/Casper, Matthias (editörler), German Corporate Governance in International and European Context, 3. Bask1, Springer, s. 40.

Spiegel, s. 121. 
yönetim kurulu üyelerinin yasal sorumluluğu da diğer üyeler ile aynıdır (TTK, m. 553).

\section{B. TANIMI}

Bağımsız yöneticiler, hakim (veya büyük) hissedarlarla veya şirketle, yönetim kurulundaki hizmetleri dışında hiçbir bağı olmayan yöneticiler olarak tanımlanabilir. ${ }^{21}$ Buna göre, şirketle belirli ekonomik bağlar da dahil olmak üzere, herhangi bir ilişki genellikle bir yöneticinin bağımsızlı̆ıını zedeleyebilecek unsur olarak kabul edilir. Bağımsız yöneticilerin tanımında yer verilen unsurlar genellikle, şirket ya da bağlı kuruluş ile olan maddi ilişkilere odaklanmıştır. Son yıllarda bağımsızlığın tanımı, ana şirket veya iştiraklerle olan iş ilişkilerinin yanı sıra şirket veya yönetimi ile belirli kişisel bağları içerecek unsurlara da yer verecek şekilde genişletilmiştir.

OECD Kurumsal Yönetim İlkeleri’nde yer verilen bağımsızlı̆̆ı kaybettiren durumlar olumsuz şartlar olarak nitelendirilir. $\mathrm{Bu}$ olumsuz şartların, gerçek bağımsızlığı artırmaya yönelik bağımsızlığın niteliğini ve mahiyetini ortaya koyan örneklemlerle tasvir edilmesi tavsiye edilir. ${ }^{22}$ Örneğin, yönetim kurulunda yeterli sayıda üyenin, şirket veya iştirakleri tarafından istihdam edilmemesi ve şirket veya yönetimiyle esaslı, ekonomik, aile veya diğer bağlarla yakın ilişki içerisinde olmaması önerilir. Olumsuz şartlara göre, ana hissedar olmak veya pay sahibi bir tüzel kişi ise o şirkette yönetici konumunda olmak bağımsızlı̆̆ zedeler. Burada ana hissedar olma tanımı önemlidir. Genellikle, ana hissedar oy kullanma haklarının en az \%10'unu elinde tutan hissedar olarak tanımlanmaktadır. Ancak bu tanıma karşılıklı tutulan hisseler dahil edilmediğinde problem ortaya çıkabilir. Örneğin, birbirine bağlı şirketlerde \%10'dan daha düşük olan karşılıklı hisselere sahip olan ortakların temsilcilerinin bağımsız olarak değerlendirilmemesi gerekir. Dolayısıyla, şirket ile herhangi bir yolla menfaat çatışması içerisinde olan kişilerin bağımsız yönetici olamayacağı kabul edilir.

21 TÜSİAD (2010) “Yönetim Kurulları için Kurumsal Yönetim Prensipleri”, Temmuz 2010, Yayın No. 2010/06-502, İstanbul, s. 15

22

OECD, s. 58. 


\section{NİTELIKKLERİ}

İcrada görevli olmayan üyelerin niteliğinin kurumsal yönetim standartlarının belirlenmesinde ve korunmasında özel bir önem taşıdığına inanılmaktadır. ${ }^{23}$ Kimlerin bağımsız üyeliğe aday gösterilebileceği, kurumsal yönetim ilkelerinde şekil şartları olarak sıralanmıştır. Esas olarak, bağımsızlıktan kasıt, bir adayın şirket yönetimde fiilen yer almaması, ve şirketin yönetimine diğer şekillerde de dahil olmaması durumudur; örneğin, payların önemli bir bölümünü elinde tutmaması gibi.

Halka açık anonim ortaklıkların yönetim kurullarında görev alacak olan bağımsız üyelerin görevleri ile ilgili yasal düzenlemeler SPK’nın yayımladığı ilgili tebliğler ile Kurumsal Yönetim İlkeleri’nde yer almaktadır. Bağımsız yöneticilerin taşıması gereken kriterler ile ilgili detaylar KY İlkeleri m. 4.3.6 altında (a)'dan (h)'ye kadar 10 maddede sıralanmıştır. Buna göre, yönetimi izlemeye ek olarak, bağımsız yöneticilerin şirket faaliyetlerine olumlu katkıda bulunabilecek tavsiyede bulunmaları, şirket ile pay sahipleri arasındaki çıar çatışmalarını izlemeleri ve azlık pay sahipleri ile diğer menfaat sahiplerinin görüşlerini temsil etmeleri beklenmektedir (KY İlkeleri, m. 4.3.6/e). Bu kapsamda, bağımsız üyelerden yönetimi izlemekle birlikte gerektiğinde şüphe duyması (doğruluğunu sorgulaması), kararlarına karşı çıkması (itiraz etmesi) ve şirket stratejisine objektif katkıda bulunması beklenmektedir.

KY İlkelerinde yer verilen bağımsız yönetim kurulu üyelerinin sahip olması gereken niteliklere göre, bağımsız üyeler; şirket işlerinin yönetiminde doğrudan veya dolaylı olarak herhangi bir görev üstlenmeyen (m. 4.3.6/a), Türkiye Cumhuriyeti vatandaşı olmasa da, görevi süresince Türkiye'de yerleşik gerçek kişi olmalı (m. 4.3.6/d), kamu kurum ve kuruluşlarında çalışıyor ise, yarı zamanlı statüye geçmelidir. Üniversite öğretim üyeleri bu şarttan muaf tutulmuştur (m. 4.3.6/c).

Bunun dışında, bağımsız üyenin kendisi, eşi ve ikinci dereceye kadar olan akrabalarının yönetim kurulu üyesi olarak görev yapacağı şirketle veya şirketin ilişkili tarafları veya bu şirketin yönetim kontrolüne sahip olduğu

23 Higgs, Derek (2002) Review of the Role and Effectiveness of Non-Executive Directors", Consultation Paper, 7 June 2002, s. 8. 
tüzel kişiler ile son beş yıl içinde herhangi bir ilişki içerisinde bulunmamalıdır (KY İlkeleri, m. 4.3.6/a). "Önemli görev ve sorumluluklar üstlenecek yönetici pozisyonunda istihdam, sermaye veya oy haklarını veya imtiyazlı payların \%5'inden fazlasına birlikte veya tek başına sahip olma ya da önemli nitelikte ticari ilişkiler" ilişki kapsamında değerlendirilir.

Bağımsız üyenin ayrıca, son beş yıl içerisinde, görev yaptığı şirketin üst düzey hizmetlerini yürüten şirketlerde çalışmamış, $\% 5$ veya üzeri ortaklığ 1 bulunmamış ve bu şirketlerin yönetim kurullarında yer alamamış olması gerekir (KY İlkeleri, m. 4.3.6/b). Bu hüküm, özellikle şirketin denetimini, derecelendirmesini veya danışmanlığını yürüten şirketlerin çalışanlarının ve yöneticilerinin, şirkete bağımsız üye olarak seçilmesini engellemek olduğu düşünülmektedir. ${ }^{24}$

$\mathrm{Bu}$ niteliklerden birinin dahi aday üyede bulunmaması bağımsız üye seçilmeye engeldir. ${ }^{25}$ Sonradan ortaya çıkacak bir durum nedeniyle bağımsızlığın ortadan kalkması durumunda ise üyelik kendiliğinden son bulur. $\mathrm{Bu}$ durumda, bağımsız üye, bağımsızlığı engelleyen durumu ve gerekçesini KAP 'ta açıklanmak üzere derhal yönetim kuruluna iletir (KY İlkeleri, m. 4.3.8).

KY İlkeleri'nde sayılan şekli bağımsızlık ölçütleri, bağımsız üyenin, şirkette sahip olabileceği azami payı belirleme, şirketle ilişkisi bulunan yakın çevresini tayin etmeye ve şirketten finansal anlamda bağımsızlığını temin etmeye hizmet ettiği söylenebilir. ${ }^{26}$ Ancak, şekli anlamdaki bağımsızlıktan öte, gerçek anlamda bağımsızlık, yönetim kurulundaki üyelerin herhangi bir kişinin, grubun veya organın etkisi altında kalmadan özgürce karar verebilmesinin mümkün olabilmesini gerektirir. KY İlkeleri, bu gerekliliği "bağımsız üyelerin görevlerini hiçbir etki altında kalmaksızın yapabilme yeteneğine” sahip olmak olarak açıklamıştır (KY İlkeleri, m. 4.3.3). Ancak,

24 Odman Boztosun, N. Ayşe (2013) Hukuksal Açıdan Bağımsız Yönetim Kurulu Üyeliği, Ankara, Seçkin, s. 67.

25 Bağımsızlık kriterlerinden bir veya birkaçını sağlamayan adayların bağımsız üye olarak seçilebilmesi için (i)haklı gerekçelerin varlığı, (ii) Kurul'un uygun görüşü, (iii)azami bir yıla kadar geçici bir süreyle sınırlı olmalıdır. Bkz. KY Tebliği, No: II-17.1, m. 6/5.

Odman Boztosun, s. 61. 
gerçek anlamda bağımsılıl̆̆ın tespit edilmesi veya ölçülmesinin önünde bir takım zorluklar vardır. Örneğin, bir üyenin şekli bağımsızlık ölçütlerinden her birini sağlamasına karşın, herhangi bir nedenle verdiği kararları gereğince sorgulamıyor veya herhangi bir kişinin veya grubun etkisi altında kalıyor ise, kişi 'görünürde bağımsızdır' ancak 'gerçekte bağımsızlık' sağlanamamıştır. Örneğin, aynı uçağa ortaklaşa sahip olmak gibi raporlanamayan ikili yakın ilişkilerin varlığı (ya da aynı dünya görüşüne sahip olmak gibi sosyal bağların varlığı) durumunda gerçek bağımsızlıktan söz edilmesi mümkün olmayacaktır. ${ }^{27}$ Bunun dışında, ilkelerde bağımsız üyelerin görev süresi ile ilgili bir üst sınır belirlenmemiştir. Dolayısıyla, üç yıllık görev süresi sona eren bağımsız yöneticilerin tekrar seçilmelerinin önünde bir engel yoktur. Uzun yıllara dayanan iş ilişkilerin bağımsızlığı zedeleyecek olması ihtimali bu bakımdan ihmal edilmiştir denebilir.

\section{GÖREVLENDİRILLMESİ VE AZLİ}

Yöneticiyi atama ve azil yetkisi, kural olarak pay sahiplerine aittir. TTK m. 364'e göre; yönetim kurulu üyeleri, esas sözleşmeyle atanmış olsalar bile, gündemde ilgili bir hüküm bulunması veya gündemde madde bulunmasa bile haklı sebeplerin ${ }^{28}$ varlığ halinde, her zaman genel kurul kararıly görevden alınabilir. ${ }^{29}$ Dolayısıyla, yöneticilerin ilk seçimi ve görevde kalmaları tamamıyla yönetim kontrolünü elinde bulunduran ortaklara bağlı olacaktır.

SPK KY İlkelerinde, bağımsız üyelerin atanma prosedürüne yer verilmiştir. Buna göre, bağımsız üye adayları, aday gösterme komitesi

27 Sandys v. Pincus, Supreme Court of Delaware, No. 157, December 5, 2016, WL 7094027. Ayrıca bkz. Bölüm IV, s. 15.

Örneğin, yöneticinin yönetim kurulu için aranan şartlara sahip olmaması veya mazeretsiz olarak genel kurul toplantılarına katılmaması haklı sebep olabilir.

Murahhas üyelerin azli ise TTK m. 375 gereğince, yönetim kurulunun devredilemez görev ve yetkileri arasındadır ve bunların görevden alınmaları, genel kurul tarafından değil, yönetim kurulu tarafından olmalıdır Bkz. Orbay Ortaç, Nurdan/Al Kılıç, Şengül (2018) “Anonim Şirket Yönetim Kurulu Üyelerinin ve Murahhasların Genel Kurula Katılması", Ticaret ve Fikri Mülkiyet Hukuku Dergisi, C:4, S:2, s. 211-238. Murahhas üyeler, yönetim ve temsil yetkisinin devredildiği üyelerdir ve bunlar genelde genel müdür veya müdür olarak görev yaparlar. 
tarafından bağımsızlık ölçütlerini taşıyıp taşımaması açısından bir değerlendirmeyi içeren bir raporla yönetim kurulunun onayına sunulur. Buna ek olarak, bağımsız üye adayı da bağımsız olduğuna ilişkin yazılı bir beyanı aday gösterme komitesine verir ( KY İlkeleri, m. 4.3.7). Yönetim kurulu, aday gösterme komitesinin raporunu dikkate alarak hazırladığı bağımsız üye aday listesini genel kurula sunar.

Bu prosedürlere ek olarak, SPK Kurumsal Yönetim Tebliği, No. II-17.1, madde 5/a'ya göre 1. Grupta yer alan şirketler ${ }^{30}$, bağımsız üye aday listesini genel kurula sunmadan önce, onay için SPK'ya göndermek zorundadır. Buna göre, genel kurul toplantısından en az 60 gün önce, bağımsız üye aday listesi, aday gösterme komitesinin raporu ve yönetim kurulu kararı ile birlikte Kurul'a gönderilir. Kurul, 4.3.6 numaralı ilkede belirtilen bağımsızlık kriterleri çerçevesinde yaptığı değerlendirme sonucunda varsa liste hakkında olumsuz görüşünü 30 gün üçünde şirkete bildirir. Kurul'un olumsuz görüş bildirdiği kişi genel kurula bağımsız üye adayı olarak sunulamaz (KY İlkeleri, m. 4.3.7).

Bağımsız üye seçiminde hakim hissedarların etkisi yadsınamaz. Mevcut sistemde, bağımsız yöneticiler görevde kalma ve yeniden atanmayı garanti almak için yönetimi elinde bulunduran ortaklara riayet etmek durumda kalmaktadır. ${ }^{31}$ Bunun yanı sıra, sosyal normlar gereği, kişilerin, kendisini belirli bir pozisyona yerleştiren bir kimseye karşı şükran duygusu hissetmeleri mümkündür. Bağımsız yöneticiler yönetime karşı tutum almaları gerektiğinde bu duyguya ters düşecekleri hissiyatı ile aksi yönde davranma baskısı hissedebileceklerdir. Tüm bunlar dikkate alındığında, hakim grup etkisi altındaki yönetim kurullarının bağımsız üye seçimi ve atamaları üzerindeki etkisini sınırlandırmak gereği ortaya çıkmaktadır. KY İlkeleri'nde belirtilen usulde, en büyük borsa şirketleri (1. Grup) için bağımsız üyelerin seçiminde

30 KY Tebliği, No. II-17.1 kapsamında kurumsal yönetim ilkelerinden zorunlu olarak uygulanacak olanların belirlenmesi ve borsa şirketlerinin dahil oldukları gruplar, bu şirketlerin sistemik önemlerine göre piyasa değerleri ve fiili dolaşımdaki paylarının piyasa değerleri dikkate alınarak her yıl SPK tarafından belirlenir. 2020 yılı için borsa şirketlerinin dahil oldukları gruplar için bkz. <https://www.spk.gov.tr/Bulten/Goster?year=2020\&no=4> s.e.t. 20.02.2020.

31 Bebchuk, Lucian A./Hamdani, Assaf (2017) "Independent Directors and Controlling Shareholders”, University of Pennsylvania Law Review, C:165, S:6, s. 1286. 
Kurul'un onayını almak bu etkiyi azaltmaya yönelik bir adım olarak nitelendirilebilir. Ancak, 2. ve 3. Grupta yer alan borsa şirketleri için belirlenecek bağımsız üyeler için Kurul onayı aranmaz (KY Tebliği, No. II17.1, m. 5/5). Dolayısıyla, Kurul tarafindan verilen bağımsızlık güvencesi sadece belirli büyüklükteki ve sınırlı sayıdaki borsa şirketleri için söz konusu olmaktadır. Bu durumda, halka açık statüde yer alan diğer anonim ortaklıklarda görevlendirilecek olan bağımsız üyelerin seçiminde, hakim pay sahiplerinin etkisini devam edeceğini kabul etmek yanlış olmayacaktır. Ancak, bağımsız üyenin KY İlkeleri’nde öngörülen bağımsızlık kriterlerini taşımadığı halde genel kurul tarafından seçildiğini düşünen pay sahipleri, ${ }^{32}$ bu genel kurul kararının iptalini dava edebilirler (TTK, m. 445). Hakim hissedarın bağımsız üyenin seçiminde ve atanması üzerindeki etkisini azaltacak bir diğer yöntem ise SPK'ya yapılacak itiraz başvurusudur. Sermayenin en az yüzde birini elinde bulunduran pay sahipleri, seçilmesi konusunda olumsuz oy kullandıkları bağımsız üye adaylarının seçilmesi halinde, Kurul'a bağımsızlık kriterlerine uyum ile ilgili ikinci bir inceleme yapması için başvurabilir. ${ }^{33}$

\section{KURUMSAL YÖNETIMM ARACI OLARAK BAĞIMSIZ ÜYELİK}

Bağımsız yöneticilerin yönetim kurullarındaki temel rolü icradan sorumlu olan üyelerin faaliyetlerini (yürütme faaliyetlerini) izlemek ve şirket stratejisinin geliştirilmesine katkıda bulunmaktır. Bu bağlamda, bağımsız yönetim kurulu üyelerinin varlığının, bir şirketin faaliyetlerinin sürdürülebilirliğine değer kattığ ifade edilir. $^{34}$ Yönetim kurullarında sadece bağımsızlık unsuruna odaklanma uluslararası alanda çok fazla eleştiri almıştır. Bağımsız üyelerin varlığının şirket performansına olumlu katkısı olduğunu ileri süren çalışmalar olduğu gibi böyle bir ilişki olmadığını savunan

32 Pay sahiplerinin genel kurul kararının iptali için dava açabilmesi, toplantıda hazır bulunup karara olumsuz oy vermeleri ve bu muhalefetlerini tutanağa geçirtmeleri halinde mümkündür (TTK, m. 446/1/a).

33 Odman Boztosun, s. 53.

34 Committee on the Financial Aspects of Corporate Governance (1992) The Cadbury Report. 
çalışmalar da mevcuttur. ${ }^{35}$ Dolayısıyla, yönetimin bağımsız olmasının hangi tür şirketlere ne derece faydalı olduğu ile ilgili literatürde henüz tam anlamıyla bir mutabakat yoktur. Yönetim kurulu üyelerinin çoğunluğunun bağımsız yönetim kurulu üyelerinden oluşması hala $\mathrm{ABD}$ başta olmak üzere gelişmiş ülkelerin çoğunluğunda norm olsa da, bağımsızlık kriterinin üyenin becerisi, deneyimi ve şirket ile ilgili bilgisi arasında "uygun bir dengede" olması gerektiği vurgulanmaktadır (bkz. Birleşik Krallık Kurumsal Yönetim Kodu, 2018; B.1). Diğer yandan, bağımsız yöneticilerde aranan bu nitelikler, bu yöneticilerin ne amaca hizmet edeceği diğer bir ifade ile bu yöneticilerden beklenen (veya onlar için tasarlanan) temel fonksiyonlar doğrultusunda değerlendirilmelidir. Örneğin, bağımsız yöneticilerin genel kurullarda hangi oranda görevlendirilmesi gerektiği hangi fonksiyona hizmet ettiklerine göre değişebilir. Benzer şekilde, bağımsız yöneticilerin izleme/gözetim ya da danışmanlık fonksiyonlarına göre bağımsızlık niteliğinin önem derecesi de farklılık gösterecektir.

\section{A. DANIŞMA ROLÜ}

Danışma işlevi, genel olarak, KY ilkelerinde belirtilen şirket faaliyetlerine olumlu katkıda bulunulması hedefini kapsar (KY İlkeleri, m.4.3.6 /e). İcrada görevli olmayan yöneticilerin ve bağımsız yöneticilerin, yönetim kuruluna tecrübeleri ile katkıda bulunmalarının yanı sıra, yenilikçi ve taze fikirler (risk alma gibi) sunmaları da beklenmektedir. Bu işlev için, yönetimden veya yönetim kontrolünü elinde bulunduran ortaklardan gerçek

35 Bağımsız üyelerin varlığı ile şirket performansı arasındaki anlamlı olmayan ilişkiye dair bkz. Prabowo, Muhammad/Simpson, Johnson (2011) "Independent Directors and Firm Performance in Family Controlled Firms: Evidence from Indonesia", Asian-Pacific Economic Literature, C:25, S:1, ss. 121-132. Bağımsız üyelerin varlığının şirket performansı üzerindeki olumlu etkisine dair bkz. Peng, Mike W. (2004) "Outside Directors and Firm Performance during Institutional Transitions”, Strategic Management Journal, C:25, ss. 453-471. Aynı doğrultuda, Borsa İstanbul'da işlem gören 64 firma üzerinde yapılan çalışmada, firma değeri ile bağımsız üyelerin oranı arasında pozitif açıdan anlamlı bir ilişki tespit edilmiştir. Bkz. Yağlı, İbrahim/Ünlü, Ulaş (2019) "Yönetim Kurulu Çeşitliliğinin Firma Değerine Etkisi: Türkiye Örneği”, Mehmet Akif Ersoy Üniversitesi İktisadi ve İdari Bilimler Fakültesi Dergisi, C:6, S:1, ss. 77-91. 
anlamda bağımsız olma şartının aranmasına gerek olup olmadığı tartışılmaktadır. ${ }^{36}$ Yine de, danışma fonksiyonunun izleme fonksiyonundan bağımsız olarak sürdürülemeyeceği ifade edilir. Bir başka deyişle, danışma fonksiyonu öncül (ex-ante) izleme işlevi olarak düşünülmektedir. ${ }^{37}$

\section{B. İZLEME/DENETİM ROLÜ}

Bağımsız yöneticilerin yönetim üzerindeki izleme/denetim faaliyetlerini kimin çıkarına göre gerçekleştireceği sorusu aslında vekalet teorisinde yer alan vekil - pay sahipleri çatışmasının da temel meselesidir. Özellikle, yönetimi elinde bulunduran hakim hissedarların bulunduğu şirketlerde, ilişkili taraf işlemlerinin onaylanması, karşı çıkılması ve soruşturulması yolu ile bağımsız yöneticilerin azlık pay sahiplerini korumak üzere izleme rolünü yerine getirmesi beklenmektedir. Diğer yandan, bağımsız üyelerin yönetim kurulu bünyesinde oluşturulan komitelerde görevlendirilmesi ile bilgiye daha iyi erişim olanağ1 sağlanarak, ${ }^{38}$ küçük pay sahipleri aleyhine oluşan bilgi asimetrisini yok etme rolünü üstlenebilirler ve şirketin varlıklarının hakim hissedarlar tarafından başka kanallara aktarımını (ya da kişisel menfaatler için kullanımını) engellemeye yardımcı olabilirler.

\section{Komitelerdeki Rolü}

KY İlkelerinde, yönetim kurulu bünyesinde oluşturulan komitelere seçilecek başkanların bağımsız üyeler arasından seçilmesi zorunlu tutulmuştur (m. 4.5.3). Ayrıca, denetimden sorumlu komitelerin tüm üyelerinin bağımsız üyelerden oluşması gerekir. Bu komitelerde ele alınan meselelerin çıkar çatışması yaratması muhtemeldir. İşte bağımsız üyeler, çıkar çatışması yaratan konularda bağımsız ve objektif değerlendirmeler yaparak yönetimin azlığa ve diğer menfaat sahiplerine karşı hesap verebilirliğini artırmaya hizmet ederler.

36 Gutiérrez, Maria/Sáez, Maribel (2013) “Deconstructing Independent Directors”, Journal of Corporate Law Studies, 13, s. 68.

37 Spiegel, s. 126.

38 Strampelli, Giovanni (2018) “How to Enhance Directors' Independence?”, The Journal of Corporation Law, C:44, S:1, s. 146. 
Denetimden sorumlu komite ve riskin erken saptanması komitesi bankalar hariç, borsa şirketleri için oluşturulması zorunlu komitelerdir (KY İlkeleri, m. 4.5.1). Bu komitelerde görev alan bağımsız üyeler, şirketin muhasebe sistemi, finansal bilgilerinin kamuya açıklanması, bağımsız denetimi ve şirketin iç kontrol sisteminin işleyişinin ve etkinliğinin gözetiminden sorumludur (m. 4.5.9).

Aday gösterme komitesine başkanlık edecek olan bağımsız üye ise, yönetim kurulunun yapısı ve verimliliği hakkında düzenli değerlendirmeler yapmak ve bu konuda yapılabilecek iyileştirmelere ilişkin yönetim kuruluna tavsiyelerde bulunmaktan sorumludur (KY İlkeleri, m. 4.5.11).

Ücret komitesi, yönetim kurulu üyelerine ve diğer icracı yöneticilere verilecek ücretlere ilişkin önerilerini yönetim kuruluna sunmakla görevlidir. Bunun yanı sıra, komiteye başkanlık edecek olan bağımsız üye, yöneticilerin ve idarecilerin ücretlendirme uygulamalarının, ücret komitesince belirlenen ilke ve kriterlere uygunluğunun gözetiminden sorumludur (m. 4.3.13). Ancak, yönetim kurulu yapılanması gereği ayrı bir aday gösterme komitesi ve ücret komitesi oluşturulamaması durumunda, kurumsal yönetim komitesi bu komitelerin görevlerini yerine getirir.

Riskin erken saptanması komitesinde yer alan bağımsız üyeler, şirketin varlığını, gelişmesini ve devamını tehlikeye düşürebilecek risklerin erken teşhisi ve tespit edilen risklere karşı gerekli önlemlerin alınmasından ve risk yönetim sistemlerini gözden geçirmekten sorumludur (KY İlkeleri, m. 4.5.12). Şirketin devamlılığını tehlikeye atabilecek mali zorlukları içeren finansal riskler dişında şirketin faaliyetleri nedeniyle (sonucu) maruz kalabileceği (yol açabileceği) bir takım başka riskler de söz konusu olabilir. Bunlar örneğin, teknoloji altyapısındaki dönüşümler nedeniyle ortaya çıkabilecek operasyonel riskler olabileceği gibi, iş modelinin güncelliğini kaybetmesi veya ticaret savaşları gibi ekonomik/politik nedenlerle mevcut pazarın kaybedilme tehlikesi gibi stratejik riskler veya dünya çapında iklim değişikliği nedeniyle ortaya çıkan riskler de olabilir. Bu risklerin yönetilmesi ve karşı tedbirlerinin alınması, şüphesiz bu tür risklerin iyi anlaşılabilmesine bağlıdır. Bağımsız yöneticilerin farklı uzmanlık alanlarından ve deneyimleri çeşitlilik gösteren 
kişilerden seçilmesi, farklı bakış açıları sayesinde bu tür risklerin daha kolay fark edilmelerini ve doğru değerlendirilmelerini sağlayacaktır.

\section{Belirli İşlemler Açısından Yönetim Kurulu Kararlarını}

\section{Onaylamadaki Rolï}

Komitelerdeki görevlerinin yanı sıra, bağımsız üyelerin üstlendiği bir diğer önemli fonksiyon ise belirli işlemler açısından yönetim kurulu kararlarını değerlendirmektir. Örneğin, ilişkili taraflarla gerçekleştirilecek işlemlerde bağımsız yöneticilerin onayının alınması zorunlu tutulmuştur (KY Tebliği, No: II-17.1, m. 9/3). Buna göre, ortaklıkların ve bağlı ortaklıkların, ilişkili tarafları ile gerçekleştirecekleri işlemlere yönelik bir yönetim kurulu kararında bağımsız üyelerin çoğunluğunun onayı aranır. Bağımsız üyelerin çoğunluğunun ilgili işlemi onaylamaması halinde, bu durum KAP 'da açıklanır ve işlem genel kurul onayına sunulur. Bağımsız üyelerin çoğunluğunun onayının aranacağı bir diğer işlem ise, olağan ticari faaliyetlerin yürütülmesi amacıyla diğer üçüncü kişiler lehine verilecek olan teminat, rehin, ipotek ve kefalet verilmesine ilişkin yönetim kurulu kararlarıdır (KY Tebliği, No. II-17.1, m. 12). Bağımsız yönetim kurulu üyelerinin çoğunluğunun söz konusu işlemleri onaylamaması halinde, muhalefet gerekçesinin KAP 'da açıklanması zorunlu tutulmuştur. Son olarak, varlık ve hizmet alımı/satışı benzeri işlemlerinde de bağımsız üyelerin çoğunluğunun onayı aranır (KY İlkeleri, m. 1.3.9). Bağımsız üyelerin çoğunluğunun işlemi onaylamaması halinde, olumsuz oyların gerekçesi KAP 'da açıklanır ve yönetim kurulu işlemi genel kurul onayına sunar.

Görüldügü üzere, bağımsız yönetim kurulu üyeleri, şirket varlıklarının yüklü ödemeler yoluyla bireysel çıkarları artırmaya yönelik işlemler için kullanılması ile ilgili yönetim kurulu kararlarını olumsuz oylarıyla engelleme yetkisine sahiptir. Aynı zamanda, söz konusu işlemler için verilen muhalefet kararları hakkında açıklama, yeterli bilgiyi içerecek şekilde kamuoyuyla ve pay sahipleriyle paylaşılır. Böylece, yönetim kurulunun şirket varlıklarını kullanma amacı ile ilgili pay sahipleri ve diğer menfaat sahipleri bilgilendirilmiş olacaktır. Bu bağlamda, bağımsız yönetim kurulu üyelerinin, 
yönetimde şeffaflığın sağlanmasında kritik bir öneme sahip oldukları söylenebilir.

\section{BAĞIMSIZ ÜYELERİN ETKİNLIĞİNIN ÖNÜNDEKİ ENGELLER}

İcrada görev almayan yönetim kurulu üyeleri komitelerde yer almak da dahil olmak üzere çeşitli görevler üstlenirler. Ancak bu üyeler, genellikle yarı zamanlı olarak görevlendirilirler. Tam zamanlı çalışan diğerlerinin aksine yarı zamanlı çalışan üyelerin görevlerini gerçekleştirmek için ihtiyaç duydukları bilgiye vakıf olamayabilirler ve bunun için gerekli olan kaynaklara erişimleri de kısıtlı olabilir. Bir yandan ihtiyaç duyulan gerekli bilgilere ve kaynaklara erişimin sağlanması için diğer yöneticilerle yakın ilişkilere sahip olmaları gerekirken, diğer yandan diğer yöneticilerin kararlarını ve işlemlerini sorgulama konusunda bağımsız ve özgür olmaları gerekecektir. ${ }^{39}$ Bu durum, bağımsız yöneticiler açısından görevlerini yerine getirmede karşılaşılan bir güçlük olarak değerlendirilebilir.

Bağımsız üyelerin karşılaşacakları bir başka güçlük ise, bazı yan ilişkiler nedeniyle yönetim kontrolünü elinde bulunduran ortaklarla aynı düşüncede olmak ve onların görüşlerini onaylamak durumunda kalmalarıdır. KY İlkeleri m. 4.3.6/e'de ifade edilen “...tarafsızlı̆̆ını koruyabilecek, menfaat sahiplerinin haklarını dikkate alarak özgürce karar verebilecek...” konumda kalabilmek, yönetim ile iyi ilişkilerini sürdürmek isteyen bağımsız yöneticiler için her durumda mümkün olmayabilir. Bağımsız yöneticilerin bağımsızlıklarını etkileyebilecek bu yan ilişkilerin neler olabileceği ile ilgili Delaware mahkemeleri bazı kararlara hükmetmiştir. ${ }^{40}$

i. Özel bir uçağın ortak sahipliği; mahkeme, bu durumun, tıpkı aile bağları gibi insanın tarafsı yargılama yeteneğini önemli ölçüde etkileyeceği çok yakın bir kişisel bağ oluşturacağına hükmetmiştir. ${ }^{41}$

\footnotetext{
${ }^{39}$ Committee on the Financial Aspects of Corporate Governance, para. 4.6.

${ }^{40}$ Bebchuk ve Hamdani, s. 1289.

${ }^{41}$ Sandys v. Pincus, s. 4.
} 


\section{ii. Yönetim kontrolünü elinde bulunduran ortaklara danışmanlık} hizmeti sağlamak; bağımsız bir yöneticinin hakim ortaklara (veya bağlı şirketlerine) belirli bir ücret karşılığı finansal danışmanlık hizmeti vermesini mahkemeler, bağımsızlı̆̆ zedeleyen bir unsur olarak tespit etmiştir. $^{42}$

iii. Hakim ortakların üzerinde önemli bir etkisi olan bir şirketin çalışanı olarak hizmet etmek; mahkemenin verdiği karara göre, bir yönetici eğer hakim ortak ile yarım asırdan fazla bir dostluğa sahip ve daha önce bağlı bir şirkette (hakim ortağın üzerinde önemli bir etkisi olan bir şirkette) üst düzey yöneticilik yapmışsa bağımsız olarak kabul edilemez. ${ }^{43}$ Ayrıca, bir yönetici hakim ortak ile yakın bir ilişki içersinde ise ya da gelecekte bir iş beklentisi içinde ise, bu durumun yöneticinin bağımsızlı̆̆ı ile ilgili sorunlar yaratabileceği düşünülmektedir.

Yukarıdaki örneklerde sunulduğu gibi, yönetim kontrolünü elinde bulunduran hakim yapıların bulunduğu şirketlerde bağımsız yöneticilerin hala hakim hissedarları memnun etmek üzere bir takım mali ve duygusal teşviklere sahip oldukları ${ }^{44}$ ve bunun da bağımsız yöneticilerin özellikle izleme (gözetim ve denetim) rollerinin etkinliğini zayıflattığı ifade edilebilir. Diğer bir ifade ile, özellikle vekil probleminin hakim hissedarlar ile azlık hissedarlar arasında olduğu şirketlerde, bağımsız yöneticilerin hakim hissedarları kontrol etme kabiliyeti ve isteği çok zayıf olabilir. Öte yandan, şirket yönetimini kontrol eden hissedarların varlığı bağımsız yöneticilerin komitelerdeki etkinliğini de önemli ölçüde etkileyecektir. Kontrol eden bir hissedar mevcut olduğunda, yönetim kurulu, komitelerin oluşumunda söz sahibi olacaktır. Dolayısıyla, bu komitelerde izleme ve gözetimi gerçekleştirecek ve yönetim kurulu kararların karşısında duracak bir muhalefet oluşmayacaktır. ${ }^{45}$ Sonuç

42 In Re Emerging Comm. Inc. Shareholders Litigation, Court of Chancery of the State of Delaware, No. 16415, June 4, 2004, WL 1305745, s. 34.

Del. County. Emples. Ret. Fund v. Sanchez, Supreme Court of Delaware, 124 A. 3d 1017, September 24, 2015, 1019, s. 6. the Behavior of Independent and Non-Independent Boards", Seattle University Law Review, C:33, S:4, ss. 809-848. 
olarak, bağımsız yöneticilerin çıkar çatışmaları doğuran kararları tarafsızlıklarını koruyarak sorgulayıcı bir şekilde gözden geçirebilmesi mümkün olmayacaktır.

İstatistiksel verilere göre, bağımsız yöneticilerin yönetim kurullarındaki etkisi giderek artmaktadır. Avrupa İmar ve Kalkınma Bankası'nın 2018 yılında yaptığı bir çalışmaya göre, Borsa İstanbul'da faaliyet gösteren şirketlerin yönetim kurulunun \%84’ü icrada görevli olmayan üyelerden, \%32'si ise bağımsız üyelerden oluşmaktadır. ${ }^{46}$ Yönetim kurulu büyüklüklerinin ortalama 9 üyeden oluştuğu dikkate alındığında her yönetim kurulunun en az 3 bağımsız üyeden oluştuğu anlaşılabilir. Ancak yine de, bu rakamların tek başına pratikte kurumsal yönetim anlayışında büyük bir değişiklik meydana getireceği beklenmemelidir. Yönetim kurullarında KY İlkelerindeki belli başlı bağımsızlık niteliklerini taşıyan yöneticilerin sayısına ulaşma, bağımsız üyeler için öngörülen fonksiyonların ${ }^{47}$ hakkıyla yerine getirildiği şeklinde yorumlanmamalıdır. Şeklen yasa tarafından zorunlu tutulan bağımsız üye kotasına uyulması, bu yöneticilerin sorumlu oldukları işlevin yerine getirildiğinin garantisi olamaz. Diğer bir deyişle, yönetim kurullarındaki bağımsız yöneticilerin sayısında yıllar içerisinde giderek bir $\operatorname{artış}^{48}$ gözlemlense de; bu, uygulamada alışılagelmiş iş pratikleri ve üst düzey yöneticiler arasındaki uzun yıllara dayanan iş ilişkilerinin son bulduğu anlamına gelmemelidir. Sonuç olarak; genelde, aynı zamanda bir başka şirkette de icrada görevli yönetici olan bağımsız yöneticiler, kendi

46 Avrupa İmar ve Kalkınma Bankası (2018) Türkiye'de Halka Açık Şirketlerin Kurumsal Yönetim Yapıları ve Uygulamaları Hakkında Araştırma Raporu, Haziran 2018, s. 22. $<$ https://www.spk.gov.tr/Sayfa/Dosya/1282> s.e.t. 21.02.2020.

47 Bağımsız üyelerin danışma ve izleme/denetim rolleri için ayrıca bkz. Bölüm IIIA, B, ss. 1315.

48 BIST şirketlerinin yönetim kurullarında bağımsız yöneticilerin oranı 2012 yılında \%23,6 iken 2017'de bu oran \%29,9'a çıkmıştır. Bkz. Ararat, Melsa/Alkan, Sevda/Aytekin, Belgin (2018) Sabancı Üniversitesi Kurumsal Yönetim Forumu, 5th Annual Report Women on $\begin{array}{lllll}\text { Board Turkey, } & \text { Ocak } & 2018, & \text { s. } & 17 .\end{array}$ $<$ https://iwdturkey.sabanciuniv.edu/sites/iwdturkey.sabanciuniv.edu/files/2018report_2018 0214_dijital.pdf > s.e.t. 21.02.2020. 
şirketlerinde de arzu edilen bağımsız yönetici rolünün dışına çıkmak istemeyecektir.

Diğer yandan, uygulamada bağımsız yöneticiler aynı zamanda birden fazla yönetim kurulunda görev alabilmektedir. Bunun nedenlerinden biri, bağımsız üyeliğin niteliklerini karşılayan üst düzey yönetici havuzunun sınırlı sayıda yöneticiden oluşmasıdır. Diğer yandan, üst düzey yöneticiler arasındaki güçlü sosyal ve iş bağlarının sonucu ortak yönetim kurulu üyeliğine yer verildiği anlaşılmaktadır. ${ }^{49}$ Sonuç olarak, birden fazla yönetim kurulunda görev alan bağımsız yöneticiler yönetim kurulu toplantılarının tamamına katılamayacaktır. KY İlkeleri m. 4.4.7'de yönetim kurulu üyesinin şirket işleri için yeterli zaman ayırması gerektiği yer alır. Üyenin şirket dışında başkaca görev almasının belirli kurallara bağlanması veya sınırlandırılması önerilmektedir. Yönetim kurulu üyesinin başka bir şirkette yönetici ya da yönetim kurulu üyeliği yapması veya herhangi bir danışmanlık hizmeti sunması halinde bu durumun çıar çatışmasına yol açmaması ve üyenin şirketteki görevini aksatmaması beklenmektedir (KY İlkeleri, m. 4.4.7). Uygulamada ise, şirketlerin, yönetim kurulu üyelerinin şirket dışında üstlenebilecekleri görevler ile ilgili olarak herhangi bir sınırlamaya gitme eğilimi yoktur. İlkelerde bu durumun zorunlu olmayan maddede düzenlenmesinden kaynaklı olarak, şirketler bu hükümlere aykırılık durumunda şu şekilde genel ve yüzeysel bir açıklamaya yer vermekle yetinmektedirler: "Yönetim Kurulu üyelerinin Şirket dışında üstlenebilecekleri diğer görevlerle ilgili olarak herhangi bir sinırlama uygulanmamaktadır”. Öte yandan, şirket dışında üstlenilen görevler sonucu gelişen sosyal bağların

49 Türk grup şirketleri arasındaki ortak yönetim kurulu üyelikleri yoluyla oluşturulan stratejik ilişkilerin ağ yapıları yöntemi ile incelendiği çalışma için bkz. İlhan Nas, Tülay/Özden Çaka, Merve/ Okan, Tarhan (2019) "Türk İşletme Gruplarında Ortak Yönetim Kurulu Üye Profili”, Yönetim ve Ekonomi, C:26, S:2, s. 640. Bu çalışmada yer alan grup şirketlerinin hem işletme grubu içerisinde hem de işletme grubu dişarısındaki işletmelerle ortak yönetim kurulu üyelerine yer verildiği tespit edilmiştir (İlhan Nas/Özden Çaka/Okan, s. 640). 
yönetim ve bağımsız yöneticiler arasındaki bilgi paylaşımını ve etkinliğini $\operatorname{artırdığı}^{50}$ aynı zamanda iş tecrübelerini de desteklediği savunulmaktadır. ${ }^{51}$

Bağımsız üyelik sisteminin bir diğer çıkmazı da yönetim kurulunun bağımsızlı̆̆ı ile firma performansı arasındaki kesin olmayan ilişkidir. Kurumsal yönetim alanındaki yasal düzenlemeler genellikle yönetim kurullarında bağımsız yöneticilerin sayısal olarak çoğunlukta olmasını savunulur iken uygulamada bağımsız üyelerin mevcudiyetinin firma performansını artırdığına ilişkin tatmin edici kanıt bulmak zordur. Daha önce yapılan nicel çalışmalarda yönetim kurullarında bağımsız yöneticilerin etkileri ile ilgili bulgular karışıktır. Bu çalışmaların sonuçları daha çok ülkeye özgüdür, dolayısıyla bu sonuçların diğer ülkelerde aynı şekilde yorumlanabileceği kuşkuludur. Örneğin, İsviçre finansal piyasasında 43 halka açık şirket arasında yapılan araştırmada, yönetim kurullarında bağımsız yönetim kurulu üyesi sayısını artırmanın (belirli bir eşiği geçtikten sonra) firma değerini düşürdüğü sonucuna varılmıştır. ${ }^{52}$ Diğer yandan, bağımsız yöneticilerin yönetim kurulu performansını iyileştirdiği hipotezini destekleyen bazı kanıtlar mevcuttur, örneğin hisse senedi fiyatının bağımsız yönetici ataması haberlerine olumlu tepkisi gibi. ${ }^{53}$ Bazı kanıtlar ise firma

50 Westphal, James D. (1999) "Collaboration in the Board Room: Behavioral and Performance Consequences on CEO Board Social Ties", The Academy of Management Journal, C:42, S:1, ss. 7-24.

51 Mans-Kemp, Nadia/Viviers, Suzette/Collins, Sian (2018) "Exploring the Causes and Consequences of Director Overboardedness in an Emerging Market", International Journal of Disclosure and Governance, C:15, S:4, ss. 210-220.

$52 \mathrm{Bu}$ çalışmada, bağımsız yönetici sayısını belirli bir eşikten sonra artırmanın yönetim kurulunda koordinasyon sorunlarına yol açacağı ve bilgi akışını güçleştirebileceği ifade edilmektedir. Buna rağmen, mevcut ve eski yöneticilerin yönetim kurulunda yer almasının firma değerini artırdğı gözlemlenmiştir. Bkz. Jentsch, Valentin (2019) "Board Composition, Ownership Structure and Firm Value: Empirical Evidence from Switzerland”, European Business Organization Law Review, 20, s. 222.

53 Rosenstein, Stuart/Wyatt, Jeffrey G. (1990) "Outside Directors, Board Independence, and Shareholder Wealth”, Journal of Financial Economics, C:26, S:2, ss. 175-191. 
performansı ile yönetim kurulu kompozisyonu arasında anlamlı bir ilişki olmadığını göstermektedir. ${ }^{54}$

\section{BAĞIMSIZLIĞIN GÜÇLENDİRILMESINE YÖNELIKK ALTERNATİF ÖNERİLER}

Mevcut sistemde, azlık statüdeki pay sahiplerinin, çoğunluk pay sahiplerinin önerdiği yönetici adaylarını onaylamaktan başka pek fazla seçenekleri yoktur. Bu sistem, çoğunluk hissedarlarının yönetim kontrolünü ellerinde tutmalarını sağlar. Bu güçlerini kaybetmek istemeyen çoğunluk pay sahipleri de bireysel menfaatlerine karşı çıkma olasılıkları daha düşük olan kişileri yönetim kuruluna aday gösterme eğiliminde olacaktır. Dolayısıyla, bağımsız üyeler üzerinde çoğunluk etkisini azaltan düzenlemelere ihtiyaç duyulmaktadır. Bu kapsamda ortaya atılan önerilerden bir tanesi, azlık hissedarların da bağımsız yöneticilerin seçiminde söz sahibi olması gerektiğini savunmaktadır. ${ }^{55} \mathrm{Bu}$ görüşe göre, en azından bir kısım bağımsız yöneticilerin seçimi hakim hissedarlar tarafından dikte edilmemelidir. Güçlendirilmiş bağımsızlık veya tam bağımsız olarak tanımlanan bu sistemde, yönetim kurulu üyelerinin çoğunluğunu atama yetkisi yine hakim hissedarların elindedir. Ancak, azlık pay sahiplerine de yönetici seçimi ve azlinde bir miktar yetki verilmesi gerektiği savunulmaktadır. Bu bölümde, bağımsız üyelerin bağımsızlığının güçlendirilmesinde azlığın yönetim kurulunda temsili yöntemleri değerlendirilecektir.

\section{A. BİRIKİMLİ OY SISTEMİ YOLUYLA YÖNETIMDE TEMSİL EDİLME}

Azınlık pay sahiplerinin yönetici seçimlerine dahil olmasının yöntemlerinden biri kümülatif (birikimli) oy sistemidir. Birikimli oylama, esas olarak, yeterince büyük bir azınlığın bir veya daha fazla sayıda kurul üyesini seçebileceği, oransal yönetim kurulu temsilini sağlar. T.C. Gümrük ve Ticaret

\footnotetext{
54 Hermalin, Benjamin E./Weisbach, Michael S. (1991) “The Effects of Board Composition and Direct Incentives on Firm Performance", Financial Management, C:20, S:4, ss. 101-112. 55 Bkz. Bebchuk ve Hamdani.
} 
Bakanlığ̣ Tebliği’ne göre, halka açık olmayan anonim ortaklıklarda, birikimli oy hakkının kullanılması için bazı şartlar koşulmuştur. Buna göre, bu sistem, yönetim kuruluna aday önerme hakkının ve oyda imtiyazın öngörülmediği şirketlerde, esas sözleşmede öngörülmek şartıyla uygulanabilir. ${ }^{56}$

Halka açık şirketler bakımından ise durum farklıdır. Eski SerPKn m. 22/v hükmü ile Kurul, birikimli oy haklarının düzenlenmesi hususunda açıkça yetkilendirilmişti. Bu kapsamda, halka açı anonim şirketlerin genel kurullarında birikimli oy hakkının kullanılmasına ilişkin esaslar bir tebliğ ile düzenlenmiş idi. Ancak, yeni SerPKn, birikimli oyun düzenlenmesi hususunda Kurul açıça yetkilendirilmediğinden, bu tebliğin yasal dayanağının kalmadığı söylenebilir. Bu gerekçe ile birikimli oy sisteminin sermaye piyasası şirketleri açısından uygulama alanının yasal olarak netleştirilmesi gerektiği savunulmaktadır. ${ }^{57}$

\section{B. IMTIYYAZLI PAYLAR YOLUYLA YÖNETIMDE TEMSIL EDİLME}

TTK 'ya göre, belirli grupların yönetim kurullarında temsil edilmesi mümkündür. Eski TTK 'da yönetim kurulunda temsil edilme hakkı tanıyan imtiyazın sadece "pay"lara tanınabileceği düzenlenmişti. 6102 sayılı TTK bu anlamda yönetim kurulunda temsil edilme hakkını, belirli pay gruplarının yanı sıra özellik ve nitelikleriyle belirli bir grup oluşturan pay sahipleri ile azlığı da kapsayacak şekilde genişletmiştir. TTK 360. madde hükmü, yönetim kurulunda temsil edilme hakkını bir imtiyaz olarak kabul etmiştir ve bu hakkın tanınmasında esas sözleşmede öngörülmek şartı koşmuştur (TTK, m. 360/2). Böylece esas sözleşmede öngörülmek suretiyle, yönetim kurulunda temsil edilme hakkı, hem belirli pay gruplarına, hem özellik ve nitelikleriyle belirli bir grup oluşturan pay sahiplerine hem de azlığa tanınabilir. Bu hükmün gereğince uygulanabilmesi, hem azlı̆̆ın hem de belirli pay sahibi

56 Gümrük ve Ticaret Bakanlığı, Halka Açık Olmayan Anonim Şirketlerin Genel Kurullarında Birikimli Oy Kullanımına İlişkin Esaslar Hakkında Tebliği, Resmi Gazete No: 28396, 29 Ağustos 2012, m. 5/1.

57

Odman Boztosun, s. 48. 
gruplarının diğer pay sahiplerinden ayrılacak şekilde tanımlanmasına bağlıdır. ${ }^{58}$ Belirli bir grup oluşturan pay sahipleri, kurucu aileler (veya belirli bir aileye mensup olanlar) veya onların soyundan gelenler, örneğin belirli bir soyadı taşıyanlar olarak belirlenebilir. Ancak, esas sözleşme, belirli bir kişinin yönetim kurulunda yer alacağı hükmünü içeremez. ${ }^{59}$

Buna rağmen, azınlık pay sahiplerinin belirlenebilir olması ve tanımlanması yalnızca yüzdelerin ifade edilmesinden daha karmaşık olabilir. ${ }^{60}$ Eğer geniş anlamda bir azlık tanımlaması yapılacak ise, bu payların \%50'sinin kontrolünü elinde tutan çoğunluk karşısındaki tüm pay sahiplerine denk gelir. Ancak, eğer azlık tanımlaması, teknik anlamdaki azlık tanımlamasını içeriyorsa (kapalı tip anonim ortaklıklarda payların \%10'unu, halka açı anonim ortaklıklarda payların \%5'ini elinde bulunduran pay sahipleri), bu pay sahiplerinin öncelikle tespit edilmesi gerekecektir. Sermaye oranlarına ilave olarak, payların pay senedi numaralarının belirtilmesi veya payların bağlı nama yazılı olmaları şartı gibi ayırt edici hususlarla birlikte azınlık tanımının esas sözleşmede yapılması önerilmektedir. ${ }^{61}$

TTK m. 360 kapsamında azlığa, belirli pay ve pay gruplarına tanınan yönetim kurulu üyeliğine aday gösterme hakkı aynı zamanda, yönetim kurulu üyesinin bu grup veya kişiler arasından seçilebilmesine de olanak tanımaktadır. Böylece, yönetim kurulu üyeleri, ya bu grup veya kişilerin arasından seçilebilecek ya da bu grup veya kişilerin belirlediği adaylar

58 Türk Ticaret Kanunu Genel Gerekçe, 26 Şubat 2011.

59 Kırca, İsmail/Çelik, Şehirali/Hayal, Feyzan/Çağlar, Manavgat (2013) Anonim Şirketler Hukuku, Cilt I, Ankara, Banka ve Ticaret Hukuku Araştırma Enstitüsü Yayını, s. 429. Ayrıca bkz. Karasu, Rauf (2015) Anonim Şirketlerde Emredici Hükümler İlkesi, 2. Bası, Ankara, Yetkin Yayınları, s. 34.

60 Pay sahipliğinin tanımlanmasının önündeki engellere örnek olarak, pay üzerindeki kayıtlı mülkiyet ile payın sağladığı haklardan yararlanmayı ifade eden ekonomik sahipliğin birbirinden ayrılması gösterilebilir; bkz. Kandemir, H. Kübra (2019) "Kurumsal Yönetim ve Şeffaflığın Güçlendirilmesinde Mülkiyet Açıklama Kurallarının Rolü ve Pay Sahipliğinin Tanımlanması Sorunu”, Muhasebe Bilim Dünyası Dergisi, C:21, S:2, ss. 427-453.

61 Aytuğar, Bilge (2019) "Oy Hakkında İmtiyazlı Pay Grubunun Yönetim Kurulunda Temsil Edilme Hakkı”, Ankara Hacı Bayram Veli Üniversitesi Hukuk Fakültesi Dergisi, C:23, S:1, s. 101. 
arasından seçilebilecektir. Yönetim kurulunda temsil edilme hakkının kapsamını ve şartlarını şirketler esas sözleşmelerinde belirleyebilirler. ${ }^{62}$ Örneğin, azlığa bir (1) yönetim kurulu üyeliği için aday gösterme hakkı tanınmışsa, bu durumda bir (1) yönetim kurulu üyesi, azlığın belirlediği adaylar arasından seçilecektir. Bu durumda, genel kurul, azlık tarafından önerilen adayı yönetim kuruluna seçmek zorundadır. ${ }^{63}$ Haklı sebeplerin varlığı durumda, örneğin önerilen adayın yönetim kurulu üyeliği için aranan diğer şartları sağlamaması halinde veya azlığın bu imtiyazı kullanmaması halinde, yönetim kuruluna üye seçme hakkı genel kurula geçer. ${ }^{64}$

Bundan başka, yönetim kurulunda temsil edilme hakkı, kurul üyeliklerinin tamamı için aday gösterme hakkı olarak da tanınabilir. Ancak TTK, halka açı anonim şirketler açısından, bu konuda bir sınırlama getirmiştir. Buna göre imtiyaz, halka açı anonim şirketlerde yönetim kurulu üye sayısının en fazla yarısı için getirilebilir (TTK, m. 360/1). Bir diğer ifadeyle, TTK m. 360 kapsamında seçilen yönetim kurulu üyelerinin sayısı, yönetim kurulu üye sayısının yarısını aşamaz. Dolayısıyla, beş (5) yönetim kuruluna sahip bir halka açı anonim şirkette, yönetim kurulunda temsil edilme hakkı tanınan imtiyazlı grup veya kişilere en fazla iki (2) yönetim kurulu üyeliği için aday gösterme hakkı bahşedilebilir. Ancak, bu sınırlama bağımsız yönetim kurulu üyeliği için uygulanmaz. Dolayısıyla, bağımsız yönetim kurulu üyelerinin tamamının belirli bir pay grubu tarafından belirlenen adaylar arasından seçilmesi söz konusu olabilir.

TTK kapsamında, yönetim kurullarında temsil imtiyazının yanında oy haklarında üstünlük tanıyan imtiyazların verilmesi de mümkündür. Oy haklarında imtiyaz tanınması durumunda, eşit itibari değerdeki paylara farklı sayıda oy hakkı verilmesi mümkün olabilir (TTK, m. 479/1/2). Peki, oyda

62 Bu tür imtiyaz haklarının tanınmasına ilişkin esas sözleşme değişikliği kararları sermayenin en az \%75 ini oluşturan pay sahiplerinin veya temsilcilerinin onayı ile alınır (TTK, m. 421/3-b). Buna ek olarak, paya tanınan imtiyazlarla ilgili esas sözleşme değişikliği yapılması veya imtiyazların kaldırılması ile ilgili konular öncelikle İmtiyazlı Pay Sahipleri Özel Kurulunun onayına sunulmalıdır (TTK, m. 454).

63 Eminoğlu, Cafer (2014) Türk Ticaret Kanunu'nda Kurumsal Yönetim (Corporate Governance), İstanbul, On İki Levha Yayıncılık, s. 116.

64

Karasu, s. 37. 
imtiyaza sahip gruplara veya kişilere yönetimde temsil (veya aday gösterme) hakkı verilebilir mi? $\mathrm{Bu}$ sorunun cevabını, imtiyaz yasağının veya sınırlandırmasının hangi durumlarda geçerli olduğuna bakarak cevaplamak gerekir. Öncelikle şunu belirtmek gerekir ki, bir paya tanınan imtiyaz hakkı on beş oyu geçemez (TTK, m. 479). Bunun dışında, imtiyazlı oyların kullanımının sınırlandığı hususlar kanunda belirtilmiştir. Buna göre, imtiyazlı pay sahipleri (i) esas sözleşmenin değiştirilmesi, (ii) yönetim kurulunun ibra edilmesi ve sorumluluk davası açılmasına ilişkin kararlarda imtiyazlı oy kullanamazlar (TTK, m. 479/3). ${ }^{65}$ Dolayısıyla, kanunda sayılan bu haller dışında, imtiyazlı paylardan doğan oy hakları ile yönetim kuruluna bağımsız üye seçtirilebilir. Bir başka ifade ile herhangi bir imtiyazlı pay grubu, ilkelerde belirtilen bağımsızlık kriterlerini sağlayan bir kişiyi bağımsız üye olarak seçtirebilir. Ancak bu hallerde seçilen bağımsız üyenin 'bağımsızlı̆̆ı', kendisini seçtiren gruba veya kişilere karşı bir minnet duygusu besleme ihtimalinden dolayı, sorgulanmalıdır. Bu kişiler her ne kadar, KY İlkeleri’ndeki bağımsızlık ölçütlerini karşılıyor olsa da gerçekte bağımsız olmayacaktır.

TTK m. 360 hükmü uyarınca belirli pay grupları tarafından önerilen yönetim kurulu üyeleri, hukuken diğer yönetim kurulu üyelerinin tabi olduğu haklara ve borçlara tabi olur. ${ }^{66}$ Tüm yönetim kurulu üyeleri, özen ve sadakat yükümlülüğü çerçevesinde şirketin menfaatini gözetmekle yükümlüdür. Dolayısıyla, imtiyazlı pay grupları arasından seçilen veya bu gruplarca önerilen yönetim kurulu üyelerinin, bu gruplardan emir ve talimat almamaları ve bu emir ve talimatlara göre hareket etmemeleri gerekir. Aksi davranışlar, özen ve sadakat yükümlülügünün ihlali anlamına gelecektir. ${ }^{67}$ Çünkü tüm yönetim kurulu üyeleri, kararlarını alırken, belirli grupların çıkarlarını değil şirketin çıkarlarını dikkate almakla yükümlüdür.

65 Bu düzenlemelere ek olarak, SerPKn. makul bir gerekçe olmadan üst üste beş yıl zarar eden ve kötü yönetilen halka açık şirketlerde oy hakkına ve yönetim kurulunda temsil edilmeye ilişkin imtiyazların Kurul kararı ile kaldırılması düzenlemesine yer vermiştir (SerPKn., m. 28). Bu düzenlemeyle birlikte Kurul, yönetim zafiyetleri nedeniyle zarar eden bir şirkette imtiyazların kaldırılmasına yetkili kılınmıştır (SPK Tebliği, No. II-28.1).

66 Kendigelen, Abuzer (1999) Anonim Ortaklıkta Yönetime Katılma Haklarında İmtiyaz, İstanbul, Beta Yayınevi.

67

Karasu, s. 145. 


\section{SONUÇ VE DEĞERLENDİRME}

Kurumsal yönetim sistemi içerisinde, yönetim kurullarında bağımsız üyelerin görevlendirilmesinin amacı, yönetim kurulu üzerinde izleme fonksiyonuna hizmet etmesi ile birlikte, yönetim kurulu kararlarının doğruluğunu sorgulaması ve gerektiğinde karşı çıkması, aynı zamanda şirket stratejisine objektif katkı sunmasıdır. Ancak mevcut sistemde, yönetim kontrolünü elinde bulunduranların olduğu şirketlerde, bu fonksiyonların bağımsız üyeler tarafından yerine getirilmesinin önünde bir takım engeller bulunmaktadır. $\mathrm{Bu}$ engeller de sonuç olarak, bağımsız üyelerin etkinliğini zayıflatmaktadır. Bağımsız üyelerin etkinliğinin, hakim hissedarlardan gerçek anlamda bağımsızlı̆̆ının sağlanması yolu ile geliştirilebileceği düşünülmektedir. Bu doğrultuda, bağımsız üyelerin seçimi ve atanmasında hakim pay sahiplerinin etkisinin azaltılarak, azlık hissedarların yetkilendirilmesi görüşü ortaya atılmıştır.

Ülkemizde azlık pay sahiplerine yönetim kurullarında temsil edilme imkanı TTK m. 360 uyarınca mümkündür. Ancak, bu hükmün uygulamada kullanılış amacı, bu yöntem için öngörülen amaç ile örtüşmemektedir. Hakim pay sahiplerinin bağımsız üyelerin seçimi üzerindeki etkilerinin, azlığa yetki verilmesi yolu ile azaltılması savunulmaktadır; ancak, yönetim kurulunda temsil imtiyazı, ülkemizde çoğunlukla yönetim kontrolünü elinde bulunduran pay sahiplerince kullanılmaktadır. Özellikle yönetim kontrolünü elinde tutmak isteyen belirli bir gruba veya aileye mensup pay sahipleri, yönetimde temsil hakkı tanıyan imtiyazların kullanılmasıyla birlikte şirketteki mevcut statülerini ve hakimiyetlerini koruma altına alma eğilimdedirler. Bu nedenle, esas sözleşmede öngörülen oy ve temsil imtiyazlarının kullanılması, yönetim kontrolünü elinde bulunduran pay sahiplerinin gücünü artırıcı unsurlar olarak görülmektedir. Bu çalışmada yer verildiği gibi, TTK ve SerPKn bu imtiyazlara bazı sınırlandırmalar getirmiş olsa da, bu imtiyazların özellikle aile şirketleri tarafından yaygın bir şekilde kullanıldığı bilinmektedir ve hatta bu uygulamaların çoğu zaman azınlık pay sahiplerinin çıkarlarını suiistimal edecek kararların alınmasında rolü olabilmektedir. Bu hususlar dikkate alındığında, kanuni düzenlemeler, imtiyazların kullanımına özellikle yönetim kuruluna bağımsız üye seçimi gibi hassas yönetimsel kararların alınmasında 
yasak getirebilir. ${ }^{68}$ Bir diğer çözüm yolu ise, yasa hükmünün açık bir şekilde bağımsız üyelerden (en az) birinin belirli hisse oranına sahip azlık tarafından seçilmesi şartını getirmesi olabilir. ${ }^{69}$

Bağımsız yönetim kurulu üyelerinin bir kısmını (en azından birini) belirleme yetkisinin azlığa tanınması, yönetim kontrolünü elinde bulunduranların, bağımsız yöneticilerin seçimi ve atamasındaki etkilerini azaltmak yönünde bir çözüm sunabilir. Ancak, bu yöntem bir takım sakıncaları da beraberinde getirir. Bunlardan ilki, bağımsız üyeyi belirleyecek azlık pay sahiplerinin tanımlanmasının ve belirlenmesinin önündeki zorluklardır. Daha sonra, bu pay sahiplerinin bağımsız üyelerin seçiminde oy kullanarak yönetime katılma isteklerinin mevcut olması gerekir. ${ }^{70}$ Alternatif yöntemlerin yaratabileceği bir diğer sakınca ise, mevcut yönetime muhalif grup tarafından belirlenen bağımsız yönetim kurulu üyesinin seçilmesi halinde yönetim kurulunda meydana gelebilecek potansiyel kutuplaşma ve gerginlik ortamıdır. Adeta bir takım gibi uyum içinde çalışması gereken yönetim kurulunda muhtemel gerginlik ve çatışmalar yönetim kurulunun dengesini bozacaktır. Yönetim kurulundaki çeşitlilik her ne kadar farklı fikir ve görüşlerin ortaya atılması ve farklı bakış açıları ile değerlendirme yapılmasına firsat verse de bu tür bir kutuplaşmanın örgütlerde kollektif karar alma sürecine zarar vereceği ve üyeler arasında birbirine karşı güven eksikliğinin ortaya çıkmasına neden olacağ 1 ifade edilmektedir. ${ }^{71}$ Bunun yanı sıra, azlık pay sahipleri tarafından seçilmiş olan bağımsız yönetim kurulu üyesinin diğer üyeler tarafından kabul görmeme riski de vardır. Bu durum, oy

68 Aynı doğrultuda, bkz. Odman Boztosun, s. 50.

69 İtalya'da halka açık şirketlere azlık pay sahiplerine yönetim kuruluna en az bir üye seçme yetkisi verme zorunluluğu getirilmiştir; bkz. Belcredi, Massimo/Enriques, Luca (2014) European Corporate Governance Institute, Institutional Investor Activism in a Context of Concentrated Ownership and High Private Benefits of Control: The Case of Italy, Law Working Paper No. 22/2013, s. 8. <https://ssrn.com/abstract=2325421> s.e.t. 21.02.2020. Buna göre, ödenmemiş hisselerin en fazla \%2,5 unu elinde bulunduran pay sahipleri tarafından sunulan aday listesinden en az bir yönetici, yönetim kuruluna seçilmek zorundadir.

71 Kocaoğlu, Necip Kağan (2010) “Anonim Şirketlerde Birikimli Oy Kullanımı”, Ankara Barosu Dergisi, C:68, S:4, s. 114. 
hakkına sahip olanların çoğunluğu tarafından seçilmemiş olan bağımsız üyelerin meşruiyetinin sorgulanmasına yol açacaktır. Bu tür sakıncalar nedeniyle, alternatif bir yöntem olarak, bağımsız üyelerin azlık pay sahipleri tarafından seçilmesi yaklaşımının faydadan çok zarara yol açma riski vardır. Bir diğer ifade ile asıl hedefi, çoğunluğun bağımsız üyeler üzerindeki etkilerini azaltmak olan bu yöntemin, yönetim kurullarında yaratacağı uyum ve güven problemleri nedeniyle, şirket menfaatini zora sokma tehlikesi vardır.

Tüm bunlara ilave olarak, ilkelerin bağımsız yöneticilerin azami görev süreleri ile ilgili bir düzenlemeye yer vermemesi önemli bir eksikliktir. Uzun yıllar süren ilişkilerin bağımsızlığa gölge düşüreceği söylenebilir. Bağımsız yöneticiler, görev yaptığı şirketteki yıllar boyu devam eden ilişkileri nedeniyle görevlerini ifada daha az sorgulayıcı ve daha çok kabule yanaşan bir yaklaşım sergileme eğilimine girebilirler. Bu nedenle, ilkelerde bağımsız yönetim kurulu üyelerinin en fazla üst üste görev yapabileceği azami süreyi (örneğin, peş peşe en fazla 9 yıl) belirlemesi önerilebilir.

Her halükarda, yukarıda değinilen alternatif yöntemlerin farklı ülkelerde ve farklı kurumsal yönetim sistemlerinde sonuçlarının farklı olabileceği gerçeği ihmal edilmemelidir. Bağımsız yönetim kurulu üyeliği gibi belirli bir amaca yönelik tasarlanan bu yönetim işlevinin, farklı kurumsal yönetim sistemlerinde öngörüldüğü şekilde gerçekleşmeme veya başarısız olma ihtimali vardır. Bunun sebebi, bağımsız yöneticilerin rolünün ve işlevinin farklı kurumsal yönetim sistemlerinde değişiklik gösteriyor olmasından kaynaklanmaktadır. ${ }^{72}$

Tüm bu hususlar ışığında, yine de bağımsız yöneticiler bir kurumsal yönetim aracı olarak Türk kurumsal yönetim sisteminde yer almaya devam edecek ise; kanaatimizce, bu üyeler için, özellikle çıkar çatışması oluşturabilecek konularla ilgili verecekleri kararlarda yol gösterici olması açısından, bağımsız denetçilerde olduğu gibi, bir etik kurallar rehberinin yayınlaması uygun olacaktır. ${ }^{73}$ Böyle bir inisiyatifi şu aşamada SPK

72 Bkz. Bölüm I ve IV.

73 Bkz. Kamu Gözetim Kurumu (2015) Bağımsız Denetçiler için Etik Kurallar, Türkiye Denetim Standartları. <https://www.kgk.gov.tr/Portalv2Uploads/files/Duyurular /v2/TDS/ET\%C4\%B0K\%20KURALLAR/2019_etikkurallar.pdf> s.e.t. 21.02.2020. 
üstlenebilir. Zaman içerisinde, şirketler ve yatırımcılar tarafından rollerinin farkına varılması ile profesyonel yönetim kurulu üyelerinin sayılarında bir artış gözlemlenebilecektir. Bu aşamaya gelindiğinde, bağımsız üyelerin tabi olacağ 1 etik standartların oluşturulmasında ve geliştirilmesine profesyonel yöneticilerin de katkıda bulunması daha sağlıklı olacaktır. 


\section{KAYNAKÇA}

Aksoy, Mehmet Ali (2013) “Türk Kurumsal Yönetim Düzenlemeleri Kapsamında Anonim Şirket Yönetim Kurulu”, Gazi Üniversitesi Hukuk Fakültesi Dergisi, C:17, S:1-2, ss. 45-76.

Anand, A./Milne, F./Purda, L. (2010) "Monitoring to Reduce Agency Costs: Examining the Behavior of Independent and Non-Independent Boards", Seattle University Law Review, C:33, S:4, ss. 809-848.

Ararat, Melsa/Alkan, Sevda/Aytekin, Belgin (2018) Sabancı Üniversitesi Kurumsal Yönetim Forumu, 5th Annual Report Women on Board Turkey, Ocak 2018. <https://iwdturkey.sabanciuniv.edu/sites/ iwdturkey.sabanciuniv.edu/files/2018report_20180214_dijital.pdf> s.e.t. 21.02.2020.

Argüden, Yılmaz (2009) Boardroom Secrets: Corporate Governance for Quality of Life, Palgrave Macmillan.

Armour, John/Hansmann, Henry/Kraakman, Reiner (2009) European Corporate Governance Institute, Agency Problems, Legal Strategies and Enforcement, Law Working Paper No. 135/2009, November $<$ https://sssrn.com/abstract=1436555> s.e.t. 21.02.2020.

Avrupa İmar ve Kalkınma Bankası (2018) Türkiye'de Halka Açık Şirketlerin Kurumsal Yönetim Yapıları ve Uygulamaları Hakkında Araştırma Raporu, Haziran 2018. <https://www.spk.gov.tr/Sayfa/Dosya/1282> s.e.t. 21.02.2020.

Aytuğar, Bilge (2019) "Oy Hakkında İmtiyazlı Pay Grubunun Yönetim Kurulunda Temsil Edilme Hakkı”, Ankara Hacı Bayram Veli Üniversitesi Hukuk Fakültesi Dergisi, C:23, S:1, ss. 93-125.

Bebchuk, Lucian A./Hamdani, Assaf (2017) "Independent Directors and Controlling Shareholders", University of Pennsylvania Law Review, C:165, S:6, ss. 1271-1315. 
Becht, Marco/Bolton, Patrick/Röell, Ailsa (2007) "Corporate Law and Governance": Polinsky, A. Mitchell \& Shavel, Steven (editörler), A Handbook of Law and Economics, Volume 2, Elsevier, ss. 829-920.

Belcredi, Massimo/Enriques, Luca (2014) European Corporate Governance Institute, Institutional Investor Activism in a Context of Concentrated Ownership and High Private Benefits of Control: The Case of Italy, Law Working Paper No. 22/2013, <https://ssrn.com/abstract=2325421> s.e.t. 21.02 .2020 .

Committee on the Financial Aspects of Corporate Governance (1992) The Cadbury Report.

Davies, Paul (2019) "Related Party Transactions: UK Model": Enriques, L. \& Tröger, T. (editörler), The Law and Finance of Related Party Transactions International Corporate Law and Financial Market Regulation, Cambridge, Cambridge University Press, ss. 361-399.

Del. County. Emples. Ret. Fund v. Sanchez, Supreme Court of Delaware, 124 A. 3d 1017, September 24, 2015, 1019.

Du Plessis, Jean J./Saenger, Ingo (2017) "An Overview of Corporate Governance Debate in Germany": Du Plessis, Jean J./Lutterman, Claus/Sandrock,Otto/Großfeld, Bemhard/Sænger, Ingo/Casper, Matthias (editörler), German Corporate Governance in International and European Context, 3. bask1, Springer, ss. 17-62.

Eminoğlu, Cafer (2014) Türk Ticaret Kanunu'nda Kurumsal Yönetim (Corporate Governance), İstanbul, On İki Levha Yayıncilık.

European Commission Recommendation 2005/162/EC of 15 Feb. 2005, 2005 O.J. (L 52) 52, 63.

Ferrarini, Guido/Filippelli, Marilena (2014) European Corporate Governance Institute, Independent Directors and Controlling Shareholders around the World, Law Working Paper No. 258/2014. $<$ https://ssrn.com/abstract $=2443786>$ s.e.t. 21.02.2020.

Financial Conduct Authority (FCA), Listing Rules (2014) Listing Regime Enhancements, Instrument. <https://www.handbook.fca.org.uk /instrument/2014/FCA_2014_33.pdf> s.e.t. 21.02.2020. 
Gordon, Jeffrey N. (2007) "The Rise of Independent Directors in the United States, 1950-2005: Of Shareholder Value and Stock Market Prices", Stanford Law Review, 59, ss. 1465-1568.

Gümrük ve Ticaret Bakanlığı, Halka Açık Olmayan Anonim Şirketlerin Genel Kurullarında Birikimli Oy Kullanımına İlişkin Esaslar Hakkında Tebliği, Resmi Gazete No: 28396, 29 Ağustos 2012.

Gürbüz Usluel, Aslı E. (2019) "İcra Kurulu”, Türkiye Barolar Birliği Dergisi, 142, ss. 357-382.

Gutiérrez, Maria/Sáez, Maribel (2013) “Deconstructing Independent Directors", Journal of Corporate Law Studies, 13, ss. 63-94.

Hermalin, Benjamin E./Weisbach, Michael S. (1991) "The Effects of Board Composition and Direct Incentives on Firm Performance", Financial Management, C:20, S:4, ss. 101-112.

Higgs, Derek (2002) Review of the Role and Effectiveness of Non-Executive Directors, Consultation Paper, 7 June 2002.

İlhan Nas, Tülay/Özden Çaka, Merve/ Okan, Tarhan (2019) “Türk İşletme Gruplarında Ortak Yönetim Kurulu Üye Profili”, Yönetim ve Ekonomi, C:26, S:2, ss. 625-650.

In Re Emerging Comm. Inc. Shareholders Litigation, Court of Chancery of the State of Delaware No. 16415, June 4, 2004, WL 1305745.

Jentsch, Valentin (2019) "Board Composition, Ownership Structure and Firm Value: Empirical Evidence from Switzerland”, European Business Organization Law Review, 20, ss. 203-254.

Kamu Gözetim Kurumu (2015) Bağımsız Denetçiler için Etik Kurallar, Türkiye Denetim Standartları. <https://www.kgk.gov.tr/Portalv2Uploads/files/Duyurular/v2/TDS/ET \%C4\%B0K\%20KURALLAR/2019_etikkurallar.pdf> s.e.t. 21.02.2020.

Kandemir, H. Kübra (2019) "Kurumsal Yönetim ve Şeffaflı̆̆ın Güçlendirilmesinde Mülkiyet Açıklama Kurallarının Rolü ve Pay Sahipliğinin Tanımlanması Sorunu”, Muhasebe Bilim Dünyası Dergisi, C:21, S:2, ss. 427-453. 
Karasu, Rauf (2015) Anonim Şirketlerde Emredici Hükümler İlkesi, 2. Bası, Ankara, Yetkin Yayınları.

Kendigelen, Abuzer (1999) Anonim Ortaklıkta Yönetime Katılma Haklarında İmtiyaz, İstanbul, Beta Yayınevi.

Kırca, İsmail/Çelik, Şehirali/Hayal, Feyzan/Çağlar, Manavgat (2013) Anonim Şirketler Hukuku, Cilt I, Ankara, Banka ve Ticaret Hukuku Araştırma Enstitüsü Yayını.

Kocaoğlu, Necip Kağan (2010) “Anonim Şirketlerde Birikimli Oy Kullanımı”, Ankara Barosu Dergisi, C:68, S:4, ss. 103-158.

Mans-Kemp, Nadia/Viviers, Suzette/Collins, Sian (2018) "Exploring the Causes and Consequences of Director Overboardedness in an Emerging Market", International Journal of Disclosure and Governance, C:15, S:4, ss. 210-220.

Odman Boztosun, N. Ayşe (2013) Hukuksal Açıdan Bağımsız Yönetim Kurulu Üyeliği, Ankara, Seçkin.

OECD (2016) G20/OECD Principles of Corporate Governance (Turkish version), OECD Publishing, Paris. $<$ http://dx.doi.org/10.1787/9789264236882-en> s.e.t. 21.02.2020.

Orbay Ortaç, Nurdan/Al Kılıç, Şengül (2018) “Anonim Şirket Yönetim Kurulu Üyelerinin ve Murahhasların Genel Kurula Katılması", Ticaret ve Fikri Mülkiyet Hukuku Dergisi, C:4, S:2, ss. 211-238.

Peng, Mike W. (2004) "Outside Directors and Firm Performance During Institutional Transitions", Strategic Management Journal, C:25, ss. 453471.

Prabowo, Muhammad/Simpson, Johnson (2011) "Independent Directors and Firm Performance in Family Controlled Firms: Evidence from Indonesia”, Asian-Pacific Economic Literature, C:25, S:1, ss. 121-132.

Rosenstein, Stuart/Wyatt, Jeffrey G. (1990) "Outside Directors, Board Independence, and Shareholder Wealth", Journal of Financial Economics, C:26, S:2, ss. 175-191. 
Sandys v. Pincus, Supreme Court of Delaware, No. 157, December 5, 2016, WL 7094027.

Sermaye Piyasası Kurulu (SPK), Kurumsal Yönetim Tebliği No. II-17.1, R. G: 28871, 3 Ocak 2014, EK-1 Kurumsal Yönetim İlkeleri.

Sermaye Piyasası Kurulu (SPK), Oy Hakkına ve Yönetim Kurulunda Temsil Edilmeye ilişkin İmtiyazların Kaldırılmasına İlişkin Esaslar Tebliği No. II-28.1, R. G: 31004, 10 Ocak 2020.

Spiegel, Torsten (2018) Max Planck Institute for Comparative and International Private Law, Independent Directors in Japan: Changing Corporate Governance, Research Paper Series No. 18/23. $<$ https://ssrn.com/abstract=3299495> s.e.t. 21.02.2020.

Strampelli, Giovanni (2018) “How to Enhance Directors' Independence?", The Journal of Corporation Law, C:44, S:1, ss. 103-150.

TÜSİAD (Türk Sanayici ve İşadamları Derneği) "Yönetim Kurulları için Kurumsal Yönetim Prensipleri”, Temmuz 2010, Yayın No. TÜSİADT/2010/06-502, İstanbul.

Türk Ticaret Kanunu Genel Gerekçe, 26 Şubat 2011.

Westphal, James D. (1999) "Collaboration in the Board Room: Behavioral and Performance Consequences on CEO Board Social Ties", The Academy of Management Journal, C:42, S:1, ss.7-24.

Yağlı, İbrahim/Ünlü, Ulaş (2019) "Yönetim Kurulu Çeşitliliğinin Firma Değerine Etkisi: Türkiye Örneği”, Mehmet Akif Ersoy Üniversitesi İktisadi ve İdari Bilimler Fakültesi Dergisi, C:6, S:1, ss. 77-91. 